\title{
KÖZLEMÉNY
}

\section{Lengyelország, Csehország és Szlovákia családtámogatási rendszereinek összehasonlítása}

\section{Farkas Tamás}

\section{ÖSSZEFOGLALÓ}

Tanulmányunkban Lengyelország, Csehország és Szlovákia családtámogatási rendszereit vetjük össze. Megvizsgáljuk a három ország pénzbeli ellátási formáit (fizetett és fizetetlen anyasági, szülői szabadságok, családi pótlékok és családi adókedvezmények), valamint a bölcsődei és az óvodai rendszereket. Mivel a jelenlegi családtámogatási modellek értelmezhetetlenek az intézményrendszerek történeti háttere nélkül, elemzésünkben ismertetjük a rendszerváltás utáni családpolitikai vitákat, és bemutatjuk hogyan politizálódott át a szakterület az elmúlt szűk harminc évben. Mindegyik országra jellemző, hogy az 1990-es években a családtámogatási rendszerek súlyos válságokat éltek át, amely oka és eredője is volt az egykori szocialista országokat sújtó demográfiai és szociális kríziseknek. Mindhárom országról elmondható, hogy a támogatási rendszerek finomhangolása általában alárendelődött az éppen aktuális politikai kurzus ideológiai szempontjainak, viszont ezek a mintázatok nem voltak mindig konzekvensek.

Tárgyszavak: családpolitika, népesedéspolitika, Csehország, Lengyelország, Szlovákia, összehasonlító elemzés

Farkas Tamás

Budai Irgalmasrendi Kórház Kht.

E-mail: tamasfarkas1987@gmail.com 


\section{BEVEZETÉS}

Tanulmányunk célja Lengyelország, Csehország és Szlovákia jelenlegi családtámogatási rendszereinek összehasonlító jellegü bemutatása. Elemzésünkben a családpolitikai intézményrendszer bizonyos területeit hasonlítjuk össze, kiemelve az egyes országok gyakorlatai és intézkedései közti különbségeket és hasonlóságokat. Mivel a jelenlegi családpolitikai gyakorlatok értelmezhetetlenek az intézményrendszerek történeti kontextusa nélkül, röviden ismertetjük a három ország rendszerváltás utáni családtámogatási modelljeit is. Családpolitikák alatt olyan közpolitikai gyakorlatok, jogszabályok és különböző juttatások összességét értjük, amelyeken keresztül a kormányzat a családok életét befolyásolja. Az egyes családtámogatási rezsimek föbb céljai több szempont mentén változnak. A családpolitikának alapvetően három területe van: a családjog (a családok helyzetét szabályozó vonatkozó jogszabályok összessége), a családok anyagi helyzetét befolyásoló támogatási rendszerek (pénzbeli támogatások, adókedvezmények, szülői szabadságolás) és a természetbeni juttatások rendszerei (gyermekellátás, gyermekvédelem, lakhatási és egyéb támogatások).

A három vizsgált ország családtámogatási rendszereit alapjaiban határozzák meg az évtizedek óta csökkenő születésszámok, az ebből fakadó demográfiai krízis érzékelése, valamint a növekvő társadalmi egyenlőtlenségek problémája. A rendszerváltás utáni értékrend-változások markánsan kihatottak a középeurópai országok társadalmainak önképére és ezen keresztül a gyermekvállalási hajlandóságra is, amely az 1990-es évek közepére mindegyik országban soha nem látott mélypontokra zuhant. Ezzel összefüggésben mindhárom vizsgált ország esetében egy állandó feszültség jellemzi a családtámogatással kapcsolatos politikai csatározásokat, amelyek legfőbb mozgatórugóját az jelenti, hogy az egyes pártok a családpolitikai intézkedéscsomagokat inkább népesedéspolitikai, vagy inkább szociálpolitikai eszközöknek tekintik. Ennek a dichotómiának a legfőbb oka abban keresendő, hogy egyrészt a rendszerváltás óta a közép-európai országok lényegében folyamatos demográfiai krízist élnek át (ez generálja a családpolitikák népesedéspolitikai fókuszát), másrészt viszont drasztikusan növekedtek a társadalmi egyenlőtlenségek is, amelyek enyhítésének egyik lehetséges módja a szociálpolitikai irányultságú családtámogatási intézkedések. Természetesen a két irányultságot nem lehet teljesen konzekvens módon elkülöníteni egymástól egy-egy párt vagy kormány családpolitikai programjaiban. Tendenciaként azonban elmondható, hogy a konzervatív pártok inkább a népesedéspolitikai irányultságot, míg a régió szociálliberális pártjai inkább a szociálpolitikai aspektusokat hangsúlyozzák a családtámogatási modellek kapcsán. 
Mivel a kiszámítható, kalkulálható, biztonságos családtámogatási rendszer meghatározó jelentőségű a gyermekvállalás szempontjából, adja magát a kérdés, hogy milyen összefüggések mutatkoznak a posztszocialista országok demográfiai válsága, illetve ezen államok családpolitikai modelljei között. A rendszerváltások után valamennyi volt szocialista ország meredek születésszám-csökkenést élt meg, a teljes termékenységi ráták mindenhol jóval a fenntartási szint alá estek. A trend olyannyira átfogónak bizonyult, hogy a fertilitási mutatók ugyanúgy romlottak a rendszerváltást viszonylag stabilan átvészelő országokban (Lengyelország, Szlovákia, Csehország, Magyarország, Szlovénia), mint a majdnem teljes gazdasági összeomlást átélő Ukrajnában és Oroszországban, a háború sújtotta balkáni államokban (Szerbia, Horvátország) és a relatíve gyorsan magukra találó balti államokban. Sobotka (2002: 51) és Rodin (2011: 222, 224) amellett érvelnek, hogy a rendszerváltások után részben leépültek vagy átalakultak azok a kockázatátvállalási rendszerek, amelyek a szocialista időszakban gyakorlatilag mesterségesen képesek voltak késleltetni a nyugaton már az 1960-as évek elején megindult második demográfiai átalakulást.

Ezzel kapcsolatban a Frejka-Gietel-Basten szerzőpáros (2016: 6) arra hívja fel a figyelmet, hogy a szocialista rendszereknek három egymást erősítő strukturális jellemzője segítette a második demográfiai átmenet késleltetését és a korai, széles körü gyermekvállalást. Egyrészt a keleti blokk országainak tervgazdálkodásalapú iparszerkezete relatíve alacsony hatékonysággal és magas munkaigénnyel működött, amely lehetővé tette a gyakorlatilag teljes foglalkoztatottság elérését. Másrészt a szocialista ideológiának integráns része volt a gyermekvállalás ösztönzése, és az állami elosztórendszerek ezt gyakorlati szinten is igyekeztek foganatosítani. Harmadrészt az autoriter pártállami rendszerek jelentősen korlátozták polgáraik szabadságát és az egyéni ambícióik kiteljesedését. Mindezen körülmények a társadalom nagyobb része számára egy relatíve stabil, kiszámítható életpályát körvonalaztak, amely ugyan a nyugatinál lényegesen szolidabb életszínvonalat, de magasabb szintű tervezhetőséget és biztonságot jelentett. Thornton és Philipov (2009: 136) szerint a rendszerváltást követően az egykori szocialista társadalmak túl gyorsan és kényszeresen vettek át bizonyos nyugati értékeket és viselkedésformákat. A szerzőpáros szerint a rendszerváltás ide-

\footnotetext{
${ }^{1}$ A második demográfiai átmenet (second demographic transition, STD) elméletet Ron Lesthaeghe és Dirk van de Kaa dolgozta ki az 1980-as évek közepén, és a teória azóta is a kortárs demográfiai elemzések alapvetését képezi. A magyarázat szerint a posztmodern társadalmak bizonyos demográfiai anomáliái (alacsony termékenység, az első gyermek születésének halasztása, a házasságon kivüli születések számának növekedése, a válások magas száma, az élettársi kapcsolat elterjedése) mögött értékváltozások, az individualizálódás folyamata, a nemi szerepek különbségeinek és a hierarchikus viszonyok oldódása, a fogyasztási kedv fokozódása és a gazdasági alapú családtervezés narratívájának megjelenése áll (van de Kaa 1987: 9).
} 
jén a nyugati családalapítási és menedzselési minták szorosan összefonódtak a prosperálás és a jólét ideáljaival. A szabadidő felértékelődése, a karrier fontosságának előtérbe kerülése, a család-munka egyensúly szisztematikus eltolódása az utóbbi javára, az oktatási rendszerben eltöltött időszak meghosszabbodása ugyanakkor a gyermekvállalási kedv csökkenéséhez vezetett.

A fentebb idézett szerzők elsősorban szociokulturális és szocioökonómiai szempontokból a rendszerváltást éles cezúraként kezelik a családtámogatási modellek történetében. Az intézményfejlődési szempontokat hangsúlyozó kutatók szerint viszont a rendszerváltások nem jelentettek túlzottan radikális váltást a közép-európai családpolitikai intézményrendszerek evolúciójában. Ferge (2017), Saxonberg (2014), Haskova et al. (2009), Blum et al. (2014) és Inglot (2016) a szocialista családpolitikai modell alapstruktúráinak változatlanságát hangsúlyozzák a volt szocialista országok kapcsán. Intézménytörténeti szinten 1989/90 nem jelentett éles váltást a családpolitikai rendszerek alakulásában: a lényegi fordulatok a rendszerváltás előtti évtizedekben zajlottak le. Bár a családtámogatási szisztémák alapvető struktúrái lényegében egyik vizsgált országban sem változtak, a részszabályozások hektikusak, kiszámíthatatlanabbak lettek, és az egész kérdéskör radikálisan átpolitizálódott.

\section{A HÁROM VIZSGÁLT ORSZÁG CSALÁDPOLITIKAI RENDSZEREINEK ÖSSZEHASONLÍTÁSI SZEMPONTJAI}

A különböző országok családpolitikai modelljei összevetésének nagy szakirodalmi hagyománya van. Az összehasonlítások között találkozhatunk olyan elemzésekkel, amelyek inkább a választott országok demográfiai és szakpolitikai helyzeteinek hasonlóságait emelik ki (például: Ocenasova-Sotirovic 2015), és természetesen vannak olyan tanulmányok is, amelyek a különbségekre fókuszálnak (Haskova-Saxonberg 2015). A földrajzi proximitás, vagy a hasonló intézménytörténeti hagyományok és intézkedéscsomagok megléte egyáltalán nem szükséges feltétele a családpolitikai összevetéseknek. Suwada és Plantin (2014) például a lengyel és a svéd családpolitikai intézkedéseket hasonlítja össze mindenekelőtt az apasági támogatások kapcsán, míg Avram és Militaru (2016) a román és a cseh adókedvezmény rendszereket vetik össze a gyermekszegénységre gyakorolt hatásuk kapcsán. Az egész közép-kelet-európai régiót elemzik részletes tanulmányukban Frejka és Gietel-Basten (2016), mindenekelőtt családpolitikai intézkedések népesedési hatásaira fókuszálva. Blum és szerzőtársai (2014) Ausztria, Szlovénia és Csehország esetében vizsgálják a pénzügyi válság hatásait a jóléti (és ezen belül a családtámogatási) rendszerek átalakítása kapcsán. 
A vizsgált három ország családpolitikai összehasonlítása szempontjából például különösen fontos kiemelni, hogy a mai Csehország és Szlovákia teljes egészében, Lengyelországnak pedig bizonyos déli területei voltak részei a Habsburg Birodalomnak (1867 után Osztrák-Magyar Monarchia), illetve mindegyik országot erőteljes német-porosz befolyás érte. Az Osztrák-Magyar Monarchia az 1850-es, 1860-as években kezdte kiépíteni a gyermekellátó rendszerek alapjait. Hasonlóan lényeges aspektus a három ország szocialista múltja, amely mind a mai napig meghatározza a családtámogatási rendszerek intézményes kereteit. A három ország a keleti blokk „nyugatosabb” államainak számítottak, mindegyiket több történelmi és kulturális kapcsolat füzi Európa nyugati részeihez (elsősorban a németajkú területekhez), mint Oroszországhoz. Ezen túlmenően (a Német Demokratikus Köztársaságot leszámítva) a három ország a keleti blokk legfejlettebb és legiparosodottabb államai voltak.

A hasonló történelmi tapasztalatok ellenére a három ország családpolitikai rendszerei sok szempontból különböznek egymástól, amely számos fontos kérdést vet fel mind a történeti aspektusok, mind a rendszerváltás utáni divergenciák kapcsán. Ezzel összefüggésben ugyanakkor jól demonstrálható a szocializmus alatt kialakult családtámogatási intézményrendszerek erőteljes determináló ereje is. Tanulmányunk ezt a „,hasonlítva különbözőséget” mindvégig igyekszik reflektálni az elemzések során.

A szakirodalmi adatok és az elérhető adatbázisok alapján a családtámogatási rendszerek alábbi szegmentumait kívánjuk vizsgálat tárgyává tenni:

- pénzbeli ellátási formák

- fizetett anyasági szabadság,

- fizetett szülői szabadság,

- családi pótlék,

- családi adókedvezmények (amennyiben van ilyen támogatási forma);

- gyermekgondozási szolgáltatások, ellátások

- bölcsőde,

- óvoda;

• egyéb kedvezmények (különböző gyermeknevelési szabadságok).

Fontos módszertani jellegü megjegyzés még, hogy minden családpolitikai rendszer és azok intézkedéscsomagjai elhelyezhetők az explicit/implicit familizáció-de-familizáció, illetve az explicit/implicit genderizing-degenderizing tengelyeken is. A familialista/familista („,családias”) narratíva a gondozással kapcsolatos teendőket alapvetően a családra hárítja, tehát egy konzervatív beidegződésú paradigmáról van szó. A de-familizáció ezzel szemben a gyermekekről való 
gondoskodás társadalmiasítását jelenti, amennyiben az állam igyekszik intenzíven szerepet vállalni a gyermeknevelés segítésében. Ennek értelmében az explicit familializmus nyíltan támogatja a nők otthoni gondoskodó munkáját (ennek egyik eszköze például a hosszan fizetett anyasági szabadság), az implicit familializmus pedig javarészt passzivitásával végső soron a családokra hárítja a gyermekgondozás feladatait (ennek tipikus esete az alacsonyszintű bölcsődei ellátás például Lengyelországban). Ezzel összefüggésben javasolja Saxonberg (2014: 3) a genderizing-degenderizing fogalompár bevezetését, amely elsősorban abból a szempontból vizsgálja a családpolitikákat, hogy azok vajon javítják, vagy esetleg rontják a nők munkaerőpiaci helyzetét. A degenderizing jellegű szociálpolitikák a hagyományos, predeterminált női szerepek lebontását igyekszenek elősegíteni: a kiterjedt gyermekgondozási rendszerek müködtetése, vagy az apák számára is elérhető szülői szabadságok bevezetése például kimondottan degenderizing elvű családpolitikáknak számítanak. Ezzel szemben explicit genderizing jellegü intézkedés például a hosszú távon folyósított anyasági támogatás, amennyiben az otthonmaradásra, ezáltal pedig a munkaerőpiactól való távolmaradásra ösztönzi a nőket. A legtöbb egykori szocialista országra igaz, hogy ezek a tendenciák felváltva és keveredve vannak jelen a családtámogatási rendszerekben, és elsősorban az intézményes status quo-k, illetve népesedés- vagy foglalkoztatáspolitikai célok miatt gyakran eltérő előjelű intézkedések élnek egymás mellett.

\section{CSALÁDPOLITIKAI INTÉZKEDÉSEK LENGYELORSZÁGBAN 1990-TÖL NAPJAINKIG}

A rendszerváltás utáni Lengyelországban a Balcerowicz-féle sokkterápiának köszönhetően a régió többi vizsgált országához képest már eleve visszafogottabban működő lengyel családpolitikai intézményrendszer szolgáltatásai tovább szükültek. Az ország családtámogatási rendszerét évtizedeken át az állam relatíve korlátozott és a katolikus egyház meghatározó szerepe, valamint egy alapvetően reziduális ${ }^{3}$ és ebből fakadóan implicit familizációs hajlam jellemezte.

\footnotetext{
${ }^{2}$ Leszek Balcerowicz lengyel pénzügyminiszter 1989 őszén körvonalazta gazdasági tervezetét, amelyben a költségvetési hiány gyors megszüntetését, az állami vállalatok rohamszerủ privatizálását, árfelszabadítást és feszes monetáris politikát szorgalmazott. A program eredményeként meglódult az infláció (különösen az élelmiszerárak emelkedtek zabolátlan módon), estek a reálbérek, és zuhant a fogyasztói kereslet.

${ }^{3}$ A reziduális jóléti modell alapelve a rászorultsági alapú támogatások rendszere, vagyis hogy a jóléti állam gondoskodása csak azokra irányul, akikállami segítség nélkül nem lennének képesek kielégítően gondoskodni magukról. Jelen esetünkben a reziduális jellegü lengyel családpolitikák (általában implicit) familizációs tendenciát hordoznak magukban, amennyiben a visszafogott állami szerepvállalás, illetve bizonyos laissez-faire szakpolitikai attitüdök (például a gyermekgondozási intézmények alacsony támogatása) automatikusan a család gondozói szerepének erősödéséhez vezetnek.
} 
Az 1990 utáni kormányok igyekeztek visszább szorítani az államot a gyermeknevelés terheinek átvállalásában, amihez már a bizonyos elemeiben a rendszerváltás előtt is reziduális alapú támogatási rendszer jó alapot biztositott. A központi kormányzatok a gyermeknevelés kapcsán a családok felelősségét és a helyi önkormányzatok fontosságát hangsúlyozták, amit bizonyos szolgáltatási rendszerek piacositása kísért. Az állam visszavonulása a gyermeknevelés támogatásából ugyanakkor nem volt egy részelemeiben koherens folyamat. Az 1990-es években jelentősen csökkent például a gyermekgondozási intézmények finanszírozása, aminek köszönhetően visszaesett az állam által fenntartott bölcsődék és óvodák száma. Csökkentek a családi pótlékokkal kapcsolatos kiadások is, növekedtek viszont a szülési/szülői támogatások (Saxonberg 2014: 231).

A ráfordítások szempontjából 1989 és 2004 között a lengyel családpolitika hosszú hullámvölgyét élte. Közvetlenül a rendszerváltás utáni megszorításokat követően a kormányzatok 1995 és 2003 között tovább csökkentették a családpolitikai kiadásokat. 2004-2005 környékén figyelhető meg fordulat a ráfordítások tekintetében. Az 1990-es évek demográfiai mélypontjára reagálva a kormányzat lassan növelni kezdte a családtámogatási ráfordításokat, leginkább a fizetett anyasági támogatások mértékét. Csökkenő tendenciát mutatott viszont a családi pótlék jellegű juttatások GDP-arányos ráfordítása (lásd: 1. és 2. ábra).

A lengyel családpolitikai narratívák hullámzása különösen kiszámíthatatlan volt az ezredforduló környékén. Az AWS (Akcja Wyborcza Solidarność) által vezetett konzervatív kormány 1999-ben 16-ról 26 hétre akarta növelni a fizetett anyasági szabadság időtartamát, ám ez megbukott a később hatalomra jutó szociáldemokraták ellenállásán. Leszek Miller baloldali, ugyanakkor piacpárti kormánya elutasította a fizetett szülői szabadság apákra történő kiterjesztését, aminek köszönhetően viszont a konzervatív ellenzék vált a nők munkaerőpiaci reintegrációjának szószólójává. 2005-ben a konzervatív Jog és Igazságosság (Prawo i Sprawiedliwość, PiS) párt által vezetett kormány a fizetett anyasági szabadság 26 hétre való emelését javasolta, miközben a baloldali ellenzék immár az apasági szabadság bevezetését kívánta elérni. 2007-ben a kormány átfogó családpolitikai programtervet terjesztett be (Program Polityki Rodzinnej), amelynek az egyik lényegi része a gyermekgondozási rendszer fejlesztése volt. A program az állami férőhelyek bővitését és a nyitvatartási idők meghosszabbítását szorgalmazta (Saxonberg 2014: 233). 
1. ábra: Anyasági támogatásokra forditott kiadások a GDP százalékában kifejezve Lengyelországban, 2000-2012

Expenditure on maternity benefits, Poland 2000-2012. Expenditures as \% of GDP

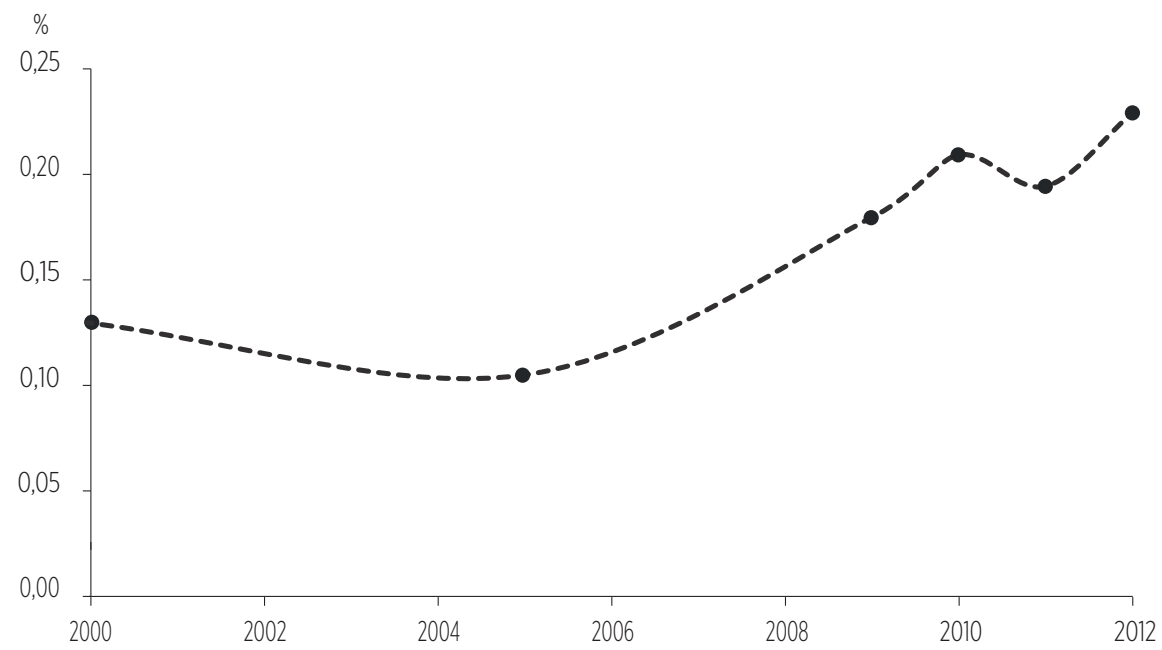

Forrás: Inglot (2016: 251) alapján saját szerkesztés.

2. ábra: Családi pótlék jellegü kiadások a GDP százalékában kifejezve Lengyelországban, 2000-2012

Expenditure on family allowances, Poland 2000-2012. Expenditures as \% of GDP

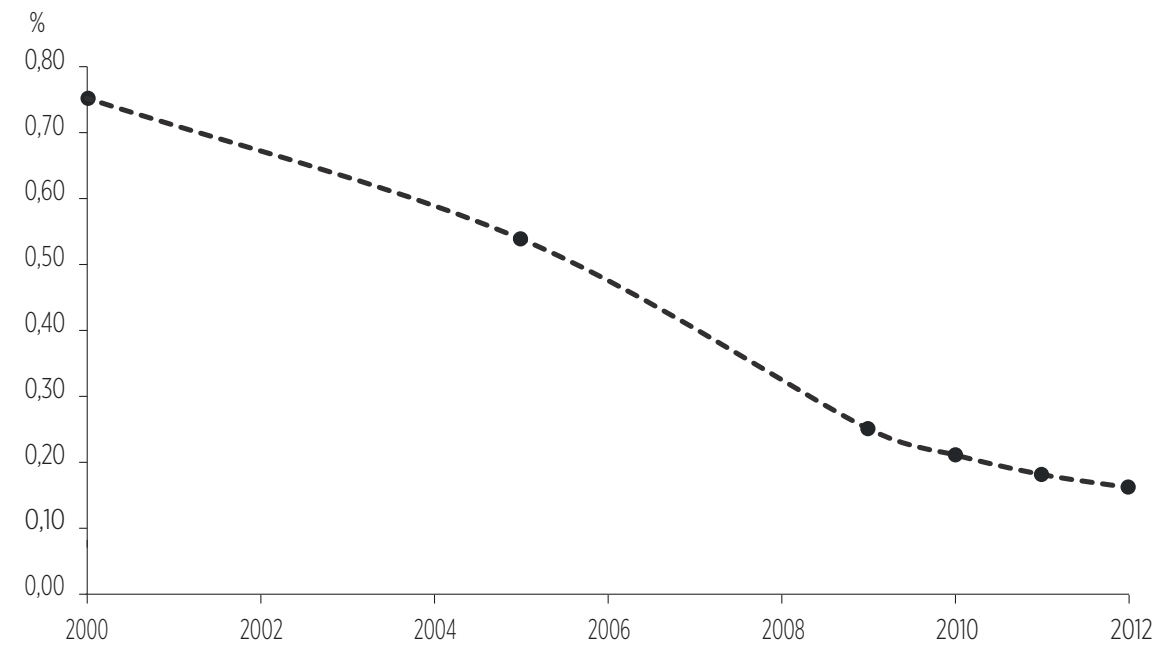

Forrás: Inglot (2016: 251) alapján saját szerkesztés. 
Saxonberg (2014: 232) és Inglot (2016: 250) is megjegyzik, hogy a lengyel családpolitikai rendszer lényegében 2005-2006 környékére stabilizálódott. A 2007-ben hatalomra kerülő Polgári Platform (Platforma Obywatelska, PO) liberálkonzervatív, kereszténydemokrata kormány lényegében folytatta a PiS családpolitikai reformjait, viszont a fizetett anyasági szabadságot 20 hétre csökkentette. A reformoknak köszönhetően 2010-ben a családpolitikai kiadások a GDP 2,68\%-át tették ki, ami ugyan javulásnak mondható az ezredforduló környéki ráfordításokhoz képest, de jócskán alatta marad a rendszerváltás kori szintnek (Inglot 2016: 250).

A 2015-ben ismét hatalomra jutott PiS-kormány Rodzina 500+ néven újabb családpolitikai intézkedéscsomagot dolgozott ki, amelynek célja a lengyel családtámogatási modell minden eddiginél átfogóbb reformja és a gyermekvállalás támogatása. A tervezet elsősorban a fizetett szülői szabadságot kivánta radikálisan kiterjeszteni a több gyermeket vállaló szülőkre, így ösztönözve a gyermekvállalást. A PiS-kormány népesedési szakértői szerint a program nagyságrendileg 2,7 millió lengyel családot érintene, és az elkövetkező tíz évben körülbelül 280 ezerrel több gyermek születhet a kiterjesztett támogatásoknak köszönhetően. A lengyel statisztikai hivatal (Główny Urząd Statystyczny, GUS) mérései szerint az intézkedés széles körü lakossági támogatást élvezett. A közvéleménykutatási adatok szerint nőtt azoknak a szülőknek a száma, akik az új támogatás hatására az első gyermek után további két vagy három gyermek vállalását tervezték, viszont nem változott lényegesen az első gyermek vállalását eldöntő párok száma. ${ }^{4}$

\section{PÉNZBELI ELLÁTÁSOK}

\section{Gyermeknevelési szabadságok}

A lengyel családpolitikai modell alapját jelentő 100\%-os bérpótlású anyasági szabadság (urlop macierzynski) hosszát és igénybevételét illetően a rendszerváltást követő kormányok számos változtatást hajtottak végre. 1999 és 2001 között a parlament több különböző időintervallumot is megvitatott a fizetett anyasági szabadság hosszával, illetve az anya által kötelezően kiveendő időtartam kapcsán. Végül 2001-ben 16 hét az anya által kötelező igénylendő szabadság mellett döntött a törvényhozás, amit plusz hat hétnyi opcionálisan felhasználható időtartammal toldott meg (ikerszülés esetén a fakultatív hosszabbítás 9 hét volt).

\footnotetext{
${ }^{4}$ https:/www.bankmillennium.pl/electronic-banking/millenet-for-individuals-business/rodzina-500-plus Letöltés: 2018. január 15.
} 
2006-ban a konzervatív PiS-kormány 18, illetve több gyermek születése esetén 28 hétre növelte az anya által kötelezően kiveendő szülési szabadságot (Szelewa 2006: 20).

Jelenleg a fizetett anyasági szabadság, amely a korábbi kereset 100\%-át jelenti, 20 hétig jár az első gyermek születésekor, 24 hétig a második gyermeknél és 28 hétig a háromgyermekes családokban. Ebből 14 hetet kötelező igénybe vennie az anyának, a fennmaradó időszakokat apai szabadságként a másik szülő is kiveheti. Igénybe vehető még ezen túl egy 6 hetes kiegészítő szülői szabadság (Kurowska-Michon 2017: 1). ${ }^{5}$ Az anya és az apa közösen kivehet 32 hét szülői szabadságot (urlop rodzicielski), amely 6 hétig 100\%-os, 26 hétig pedig 60\%-os bérhelyettesítési aránnyal kalkulálódik (Kurowska-Michon 2017: 2). Létezik még egy 100\%-os bérhelyettesítéssel müködő kéthetes apasági támogatás is (urlop ojcowksi), amelyet az apa bármikor kivehet a gyermek születését követő 24 hónapban. ${ }^{6}$

2002 óta mindkét szülő igénybe veheti a három évben maximalizált fizetett, illetve fizetetlen gyermeknevelési szabadságot (urlop wychowawczy). Ez a maximum 3 éves gyermeknevelési szabadság azonban már rászorultsági alapon működik és munkavállalói viszonyhoz között (180 nap megelőző munkaviszony), vagyis automatikus, univerzális kifizetés nem kötődik hozzá. A támogatás mértéke kezdetben jövedelemarányos, később átalánydíjú fix kifizetés, jelenleg havi 574 zloty (Kurowska-Michon 2017: 3). A fix állami dotálás összegét a kormányzat 1996 óta a fogyasztói árváltozáshoz, nem pedig a reálbérek mozgásához indexálja, aminek köszönhetően a 2000-es évek intenzív bérnövekedése miatt csökkent a támogatások mértéke (jelenleg a bruttó átlagbér körülbelül 15-16\%-a). Az egyedülálló szülők számára külön támogatási mechanizmus müködik (odatek z tytułu samotnego wychowywania dziecka), ami gyermekenként havonta 185 zloty plusz juttatást fizet ki, de maximum 370 zlotyit. A beteg gyermeket egyedül nevelő szülők számára ez a támogatás havi 265 zloty, maximum 530 zloty. ${ }^{8}$

A fogyasztói árindexált, rászorultsági alapú támogatási mechanizmusnak köszönhetően a gyermeknevelési szabadság központi mivolta ellenére sem számít különösebben bőkezűnek, ami különösen nyilvánvalóvá válik akkor, ha a többi vizsgált állam hasonló rendszereit is figyelembe vesszük. ${ }^{9}$ A rászorultsági krité-

\footnotetext{
${ }^{5}$ http://ec.europa.eu/social/main.jsp?catld=1124\&langld=en\&intPageld=4718 Letöltés: 2018 . január 15.

${ }^{6}$ http://www.leavenetwork.org/fileadmin/Leavenetwork/Annual_reviews/2016_Full_draft_20_July.pdf Letöltés: 2018. január 15.

${ }^{7}$ 2017-ben 574 zloty az egy före vetített bevétel alatt.

${ }^{8} \mathrm{http}: / /$ ec.europa.eu/social/main.jsp?catld=1124\&langld=en\&intPageld=4718 Letö|tés: 2018 . január 15.

${ }^{9}$ Mindezt csak tovább súlyosbítja, hogy emellett erősen korlátozó a családi pótlékszerủ juttatások köre, valamint hagyományosan alacsony a gyermekgondozási intézményháló finanszírozása.
} 
riumokat a kormányzat az inflációs rátához indexálja, ami miatt viszont magas inflációs időszakokban túl sokan eshetnek ki a támogatási körből. Ez oda vezet, hogy az infláció változásainak függvényében erősen fluktuál a támogatásra jogosultak köre.

További problémát jelent az is, hogy bár a szülői szabadság különböző formái elvben elérhetők az apák számára is, a férfiak igénybevételi aránya nagyon alacsony. Az apák 2002 óta vehetik ki a 20 hetes anyasági szabadság utolsó 6 hetét, illetve 2009-től élhetnek a 6 hetes kiegészitő szülői szabadsággal is. Létezik még továbbá egy 2010-ben bevezetett apasági szabadság is, amelynek keretében elvileg 38 hétig az apa veheti igénybe a fixösszegủ támogatást. Mindezzel együtt az állam még mindig nem ösztönzi elég erősen az apák támogatásigénylését. Mivel a férfiak általában lényegesen jobban keresnek, mint a nők, az alacsony fixösszegú kifizetések mellett az apáknak egyszerủen nem éri meg a támogatás igénybevétele (Suwada-Plantin 2014: 511). A jövedelemteszt alacsony összeghatára miatt a dotált szülői szabadságot döntően a rosszabbul kereső és alacsonyabb iskolai végzettséggel rendelkező anyák preferálják. A relatíve szűkmarkú, ugyanakkor hosszan igénybe vehető támogatás teljes kihasználása lényegesen rontaná a magasabb pozíciókban dolgozó anyák visszatérési lehetőségét a munkaerőpiacra, ezért a jobb keresetű nők vagy hamarabb mennek vissza dolgozni, vagy inkább elhalasztják a gyermekvállalást.

Fontos megjegyezni, hogy a PiS hatalomra jutása után a lengyel családtámogatási modell éppen átalakulási fázisban van. A 2016-ban elfogadott Rodzina 500+ családpolitikai program jelentős változásokat kiván foganatosítani a gyermeknevelési támogatások rendszerében. A program univerzálisan elérhetővé kívánja tenni az eddig jövedelemtesztelt szülői szabadságot. Ennek értelmében az állam a második gyermek vállalása után 500 zloty támogatást kiván folyósítani minden családnak, valamint az egy gyermeket vállaló, de 800 zloty alatti egy főre eső jövedelemmel rendelkező családok számára. Ez az intézkedés minden korábbinál szélesebb körben tenné hozzáférhetővé a fizetett szülési támogatást, miközben a 2014-es összegekhez képest megduplázná a családon belül egy főre eső kifizetést (295 zloty), ami a gyermek 18 éves koráig vehető igénybe. A tervezet a támogatások folyósitását és a felhasználás jogszerűségét a helyi önkormányzatokra kívánja bízni, amelyek az esetleges visszaélések esetén bizonyos retorziókat léptethetnek életbe (például a pénzbeli kifizetéseket természetbeni juttatásokra cserélhetik, vagy meg is szüntethetik a támogatások kiutalását). Számítások szerint a program évente 20-22 milliárd zloty (körülbelül 5 milliárd euró) többletterhet ró a költségvetésre, amit a lengyel kormány újabb adók bevezetéséből fedezne (Sowa 2016: 1). 
A Rodzina 500+ programot intenzív társadalmi vita és egyeztetési folyamat kíséri. A tervezet bírálóinak egy része szerint a túlzottan drága, hosszú távon nem fenntartható támogatási rendszer helyett célszerübb lenne bizonyos egyéb gyermeknevelés-segítő rendszerekre fókuszálni (például a bölcsődei-óvodai ellátás fejlesztése, az apák hatékonyabb bevonása a gyermeknevelés folyamatába, a rugalmasabb munkavállalás biztositásának törvényi elősegítése stb.). A szakszervezetek szerint a program rontja az egygyermekes, alacsonyabb keresettel rendelkező családok helyzetét. Más kritikusok azt emelik ki, hogy az új intézkedések sok esetben átfedésben lesznek a korábbi támogatási formákkal, miközben bizonyos rétegek továbbra is kivül maradnak a támogatási körön. Sokat bírált pontja a tervezetnek az is, hogy a kiterjesztett támogatások igénylésének felső jövedelemszintjeit nem kívánja maximalizálni, vagyis az egynél több gyermeket vállaló, jobb anyagi helyzetben lévő családokat is ugyanolyan volumennel kívánja támogatni, mint a legszegényebb családokat (Sowa 2016: 1-2).

\section{Családi pótlékok}

A fix összegú családi pótlékot 1995-ben a lengyel kormány rászorultsági alapúvá tette, és 25-ről 20 évre mérsékelte a gyermek életkorához kötött igénybevehetőséget. A kormány 2004-ben újradefiniálta a rászorultsági korlátokat: aktuális árfolyamon számolva 504 zloty-ban maximalizálta az egy családtagra eső jövedelemküszöböt (a tartósan beteg gyermeket gondozó családok esetében a maximum küszöb 583 zloty volt). A gyermek életkorához kötöttség 18, illetve 21 évre változott, attól függően, hogy jár-e még iskolába a gyermek. Felsőfokú tanulmányok végzése, illetve a gyermek igazolt fogyatékossága esetén a családi pótlék 24 éves korig igényelhető. A családi pótlék összegét 2004-ben 43 zlotyban állapították meg egy, illetve két gyermek, 53 zlotyban a harmadik és 66 zlotyiban a négynél több gyermek esetében (Kolaczek 2007: 41). A rászorultsági kritériumok változatlanul hagyása mellett 2006-ban a kormány a gyermek(ek) életkora alapján tovább differenciálta a családi pótlék igénylésének lehetőségeit. 5 éves korig 48 zloty, 6-18 éves korig 64 zloty, 18 és 24 éves kor között továbbtanulás esetén 68 zloty volt a családi pótlék igénybe vehető összege (Kolaczek 2007: 41). A támogatási mechanizmusból világosan kiderül, hogy a családi pótlék leginkább a rászoruló és a gyermekeiket taníttató családok helyzetét hivatott segíteni. 2016-ban ugyanezekkel az életkori sávokkal a vonatkozó összegek 89, 118, illetve 129 zloty voltak.10

\footnotetext{
${ }^{10} \mathrm{http}: / /$ ce.europa.eu/social/main.jsp?catld=1124\&langld=en\&intPageld=4718 Letöltés: 2018 . január 15.
} 
A gyermekek oktatását segíti még az iskolakezdéskor folyósitott extra családi pótlék (dodatek z tytułu rozpoczęcia roku szkolnego, nagyságrendileg 100 zloty augusztusban). Ez az iskolakezdési támogatás az első osztály megkezdésétől 21 éves korig folyósitható, és az iskolakezdés költségeinek körülbelül 18-20\%-át fedezi. Az állam külön támogatja a beteg vagy tartósan fogyatékos gyermekek iskoláztatását is. 5 éves kor alatti fogyatékos gyermek esetén havonta 80 zlotyval, 5 és 24 éves kor között pedig havi 100 zlotyval segíti az állam a tanulmányok folytatását." Ezen kívül az állam támogatja a lakóhelyüktől messze tanuló gyermekeket is, az év tíz hónapjában nyújt havi 63 zloty „ingázási támogatást” (dodatek z tytułu podjęcia przez dziecko nauki poza miejscem zamieszkania).12

A rászorultsági alapú családi pótlék a gyermeküket taníttató legszegényebb családok számára segélyszerü jövedelemkiegészítésnek számít. Minél szegényebb a család, a családi pótlékok annál nagyobb részét teszik ki a családon belüli egy főre számított bevételeknek. A mindenkori szegénységi küszöbhöz mérten $^{13}$ az átlag családi pótlék kifizetések két iskoláskorú gyermek esetén az egy före számított családon belüli jövedelem körülbelül 8-10\%-át teszik ki. Három gyermek esetén ugyanez az arány magasabb, 15\% körüli. Ha az arányt a családi pótlék mindenkori rászorultsági küszöbértékéhez mérjük, akkor 2 gyermek esetén az egy före számított családon belüli jövedelem 5-6\%-át, 3 gyermek esetén pedig nagyságrendileg 10\%-át jelentik.

A családi pótlékrendszer kritikusai szerint viszont a rászorultsági kritériumok túlságosan szigorúak, így ezek a juttatások meglehetősen szűk kört képesek támogatni. Ahogyan azt Inglot (2016: 250) megjegyzi, az 1990-es években még relative bőkezűnek számító lengyel családi pótlékrendszer GDP-arányos ráfordításai a 2000-es években folyamatosan estek (2. ábra), elsősorban a jogosultsági jövedelemkorlátok túlzottan ritka emelése eredményeként. A szigorú rászorultsági kritériumok miatt egyre többen estek ki a támogatottak köréből, amit jól mutat, hogy a családi pótlék jellegủ kiadások a 2000-es 0,80\%-ról a GDP 0,20\%-a alatti értékre csökkentek 2012-re.

Mivel az egymást követő lengyel kormányok a családi pótlékszerű juttatásokat alapvetően egyfajta jövedelemkiegészitésként kezelték, a támogatások intenzitása periodikusan és kiszámíthatatlanul váltakozott a gazdasági-társadalmi válságok vagy felívelések ritmusában. A kormányzatok azonban jellemzően nem a rászorultsági kritériumok határait kalibrálták újra (ami a támogatottsági kör nagyobb

\footnotetext{
" http://ec.europa.eu/social/main.jsp?catld=1124\&langld=en\&intPageld=4718 Letöltés: 2018 . január 15.

12 http://ec.europa.eu/social/main.jsp?catld=1124\&langld=en\&intPageld=4718 Letöltés: 2018 . január 15.

${ }^{13}$ A lengyel statisztikai hivatal 2006-ban 330, 2012-ben pedig 457 zlotyban állapitotta meg a szegénységi küszöböt. http://rszarf.ips.uw.edu.pl/pdf/emin_pl.pdf Letöltés: 2018. január 15.
} 
ütemű bővüléséhez vezetett volna), hanem újabb, relatíve szűk rétegeket érintő jogcímeket vezettek be, ami a jövedelemkorlátok változatlansága miatt nem vezetett a támogatottak körének érdemi bővüléséhez (Inglot et al. 2012: 29). A családi pótlékszerü juttatások hullámzásának másik fontos oka az, hogy a lengyel kormányzatok (a szülési szabadsággal szemben) a pótlékoknak nem tulajdonítottak különösebb születésösztönző potenciált. Inkább a társadalmi feszültségek kezelésére szolgáló szociálpolitikai eszközként funkcionál, mintsem népesedéspolitikai eszközként.

A családi pótlékkiadások csökkenésében az is szerepet játszott, hogy a szocializmus időszakában a lengyel társadalombiztosítási hivatal (Zakład Ubezpieczeń Społecznych, ZUS) családi pótlékkasszája az állami tulajdonú vállalatok különböző hozzájárulásaiból töltődött fel, amely mechanizmust a privatizáció alapjaiban érintette. A nagy állami vállalatok fokozatos megszűnése egyrészt elapasztotta a családi pótlékkasszát, másrészt az állami foglalkoztatás nagyarányú visszaszorulásával átalakult a pótlékok politikai státusza is (Inglot 2016: 253). A PiSkormány jelenleg a családi pótlék rászorultsági korlátjának radikális emelését tervezi. 2017 novemberétől az egy főre számított családi jövedelemnek 754 zloty (fogyatékos gyermek nevelése esetén 844 zloty) alatt kell lennie ahhoz, hogy a szülők igényelhessék a támogatást. A kormány ugyanakkor igyekszik azokat a családokat is segíteni, amelyek éppen a jövedelmi küszöb felett helyezkednek el, ezért nem igényelhetik a családi pótlékot. A 2016 óta ún. „Złotówka za złotówke”” (,zlotyért zlotyit”) rendszerben a kritérium feletti jövedelemsávban elhelyezkedő családok a korlátot meghaladó mértékben redukált juttatást kapnak.14

\section{GYERMEKGONDOZÁSI SZOLGÁLTATÁSOK}

\section{Bölcsődei ellátás}

A lengyel gyermekgondozási szolgáltatások fejletlenségének összetett történeti okai vannak. Mivel Lengyelország egészen az első világháborúig nem létezett egységes államként, eleve jóval kevesebb óvoda jött létre, mint például Csehszlovákiában (vagy Magyarországon), bölcsődék pedig egyáltalán nem voltak. A két világháború között az ország súlyos gazdasági nehézségekkel küzdött, ezért képtelen volt szilárdabb jóléti rendszereket kiépíteni. Ezen kívül jelentős volt az anyák nevelésben betöltött szerepét hangsúlyozó katolikus egyház, valamint a konzervatív nőszervezetek befolyása is, amelyek egyaránt a bölcső-

\footnotetext{
${ }^{14}$ http://ec.europa.eu/social/main.jsp?catld=1124\&langld=en\&intPageld=4718 Letöltés: 2018 . január 15.
} 
dei-óvodai ellátás kiterjesztése ellen foglaltak állást (Inglot 2008: 236). Bár a szocializmus évtizedeiben a lengyel gyermekgondozási rendszer is bővült, a fejlődés üteme regionális összevetésben meglehetősen visszafogott volt (az első bölcsődék például csak az 1950-es évek végén nyitottak meg). A rendszerváltás után az állam által finanszírozott bölcsődei és óvodai helyek száma, illetve az ilyen gondozóintézményekbe járó gyermekek aránya drasztikusan visszaesett, és csak 2010 után kezdett ismét növekedni.15

A lengyel bölcsődei rendszer különösen megsínylette a rendszerváltás utáni időszakot (1. táblázat). 1989-ben a 3 éves kor alatti gyermekek körülbelül 5\%-a járt bölcsődébe, 2002-re 3\%-uk, 2008-ban pedig már csupán 2\%-uk.16 1989-ben 1553, 1992-ben 818, 2001-ben 396, 2005-ben pedig 371 bölcsőde volt az országban. 2011-ben a kormány törvényben gondoskodott a bölcsődék számának növeléséről, aminek eredményeként 2012-ben 791-re emelkedett az állami intézmények száma. Szintén a rendszerváltás utóhatásaihoz köthető lényeges változás, hogy gyorsan esni kezdett az állami nagyvállalatok által alapított, a munkavállalóik gyermekei számára fenntartott bölcsődei férőhelyek száma. 1990-ben 20 ezer ilyen férőhely volt, 1991-ben 15 500, 1992-re pedig mindössze 3200 maradt. Az 1990-es évek közepére ez az opció lényegében megszűnt, és a munkavállalók számára kedvezményesen hozzáférhető helyek eltünése tovább rontotta az egyébként is alacsony bölcsődelátogatási mutatókat (Lange-Fratzak 2010: 97). Fontos különbség mutatkozik még a bölcsődei elérhetőség tekintetében a vidéki és a városi régiók vonatkozásában.17 A ZUS 2000-es adatai szerint 157 járásban (powiat) egyáltalán nem volt bölcsődei ellátás (42\%), míg a járások 28\%-ában csak a 3 év alatti gyermekek maximum 2,5\%-a számára volt elérhető ellátás. Ezek a feltételek valószínüleg javultak a 2010-es években, friss adatok azonban egyelöre nem állnak rendelkezésre. ${ }^{18}$

\footnotetext{
${ }^{15}$ http://www.transmonee.org/database/ Early childhood care and Pre-primary education (ISCED 0). Letöltés: 2018. január 15 ${ }^{16}$ A lengyel gyermekgondozási hálózat fejletlenségének tudható be, hogy a szakirodalom nem közöl teljesen pontos és egyező adatokat a bölcsődébe és óvodába járó gyermekek számarányairól.

17 Fontos módszertani megjegyzés valamennyi vizsgált ország bölcsőde- és óvodarendszere kapcsán, hogy az ellátórendszerben tapasztalható kapacitásegyenlőtlenségek javarészt az intézményes struktúra ún. kvázi racionális elosztásából, a regionális demográfiai különbségekből, valamint az intézményi háló alapvető merevségéből táplálkoznak. A statisztikailag kvázi racionális elosztás azt jelenti, hogy a nagyobb településektől a kisebbek felé haladva növekszik az 1000 lakosra jutó férőhely-ellátottság. Viszont a regionális demográfiai egyenlőtlenségek miatt a nagyobb városokban mindig intenzivebb lesz a férőhelyek iránti igény, mint a kisebb településeken. Utóbbiak a lakosság korösszetétele miatt sokszor időszakos kapacitás-leépitési pályára kényszerülnek, amelyet aztán igény esetén nehezen tudnak pótolni, míg a fiatal korfájú nagyobb városokban folyamatos lesz a férőhelyhiány. Mindez azt jelenti, hogy még az igényeket jócskán meghaladó férőhelyszámok mellett is beáll az ellátórendszerbe be nem férő gyermekek száma, amely a fenti tényezők összjátékából adódóan általában meglepően konstans értékeket mutat.

${ }^{18}$ A legutolsó elérhető adatok szerint 2007-re 133-ra csökkent a bölcsőde nélküli járások száma (Lange-Fratzak 2010: 101).
} 
1. táblázat: Az állami bölcsődék és férőhelyeik száma, valamint az ellátásban részesülő gyermekek száma Lengyelországban

Number of state nurseries and their places for children in Poland and the number of children attending nurseries

\begin{tabular}{ccccccc} 
Megnevezés & 1989 & 1992 & 2005 & 2008 & 2011 & 2012 \\
\hline $\begin{array}{c}\text { Bölcsődék száma / } \\
\text { bölcsődei férőhelyek száma }\end{array}$ & $1553 /$ & $818 /$ & $371 /$ & $392 /$ & $523 /$ & $791 /$ \\
$\begin{array}{c}\text { Bölcsődei ellátásban részesülő } \\
\text { gyermekek számaa) }\end{array}$ & 137500 & 58000 & 25000 & 29200 & n.a. & n.a. \\
\hline
\end{tabular}

Forrás: Lange-Fratczak (2010), Szelewa (2006), https://www.premier.gov.pl/en/news/news/the-number-ofnurseries-in-poland-is-growing.html. Letöltés: 2018. január 15.

Megjegyzés: a) A bölcsődei férőhelyek száma és az ellátásban részesülő gyermekek száma közti jelentős különbséget az okozza, hogy a kisgyermekek relatíve rövid időt tartózkodnak a bölcsődékben. A gyors rotációnak, a szezonalitásnak és a körülbelül 30\%-os hiányzási rátáknak köszönhetően a beíratott gyermekek valós jelenléti aránya körülbelül 70\%os. 2009-ben egy gyermek átlagos bölcsődei jelenléti időtartama 77 nap volt.

Jelenleg Lengyelországban 20 hetes koruktól 3 éves korig (kivételes esetben 4 éves korig) járhatnak a gyermekek bölcsődébe (żłobki), egy bölcsődei gondozó maximum 8 gyermekre felügyelhet (speciális gondozási igények esetében maximum 5 gyermekre), napi maximum 10 órában. ${ }^{19}$ Érdekes módon a lengyel törvények szerint a bölcsődék továbbra is egészségügyi intézményeknek számítanak, és müködésüket az 1991-es egészségügyi intézményekre vonatkozó alaptörvény szabályozza (ez egyértelmüen mutatja a szocializmus idején kialakult intézményes struktúrák napjainkig tartó szerepét). Ennek köszönhetően a bölcsődéknek rendelkezniük kell a törvényben meghatározott, egészségügyi szakképesítéseket is birtokló gondozókkal és megfelelően képzett vezetőséggel.

A bölcsődék fenntartása önkormányzati hatáskörbe esik, viszont fix állami normatívát nem kapnak az önkormányzatok. A bölcsődéket fenntartó önkormányzatok ${ }^{20}$ igényelhetnek külön állami támogatásokat az üzemeltetésre és az étkeztetésre, illetve árkedvezményeket bizonyos tejtermékek beszerzésére (Lange-Fratzak 2010: 100). A kevés férőhely miatt a bölcsődei helyekhez való hozzáférés vagy nagyon szigorúan meghatározott jövedelmi feltételekhez kötött, vagy magas térítési dijakat kell fizetni. Az igényeket magánbölcsődék (opiekun dzienny), illetve regisztrált és licenszelt gyermekfelvigyázók igyekszenek enyhíteni, ám általában mindkét megoldás meghaladja az átlagos jövedelmủ lengyel családok lehetőségeit. Egy 2007-es szabályozás szerint a magánintézményekre

\footnotetext{
${ }^{19}$ https://www.mpips.gov.pl/en/care-for-children-under-the-age-of-3/ Letöltés: 2018. január 15.

${ }^{20}$ A 2011-es bölcsődebővitési törvényekig több száz helyi önkormányzat semmilyen bölcsődei szolgáltatást nem biztosított.
} 
nem vonatkoznak a hatályos állami szabályozások, viszont nem is igényelhetnek külön állami támogatásokat (Lange-Fratzak 2010: 100).

\section{Óvodai ellátás}

Lengyelországban 12308 óvoda (przedszkole) müködött 1990-ben, 2005-re ez a szám 7738-ra esett vissza. Az 1990-es évek második felében a kormányok befagyasztották az óvodák finanszírozásának emelését, ami csak 2004-ben változott, amikor az állam növelni kezdte a férőhelyek számát. Emellett a lengyel óvodarendszer jelentős segítséget kapott különböző nemzetközi forrásokból. A Comenius Alapítvány EU-s, norvég alapos és amerikai támogatással segítette a vidéki óvodák alapítását, így 2008-ra már több mint 8000 óvoda volt Lengyelországban (Inglot 2016: 255). A GUS adatai szerint 2017-ben 11762 óvoda működött az országban. A pozitív tendenciák eredményeként az elmúlt években folyamatosan növekedett az óvodába járó gyermekek száma és aránya (jelenleg 1100700 óvodai férőhely áll rendelkezésre). ${ }^{21}$

A szakirodalmi adatok összevetése ugyanakkor meglehetősen nehézkes, mivel az egyes tanulmányok eltérő módon kalkulálják az óvodai ellátásban (3-6 éves korig), valamint az 5-6 éves korban kötelező iskola-előkészítői oktatásban (oddział przedszkolny) részt vevő gyermekek számát. ${ }^{22}$ Nagyarányú eltérések mutatkozhatnak amiatt is, hogy a különböző kutatások 3 és 6 éves kor között eltérő életkorokra vetítve mérik az óvodalátogatási arányokat. Az adatok ennek fényében meglehetősen nagy és nehezen követhető szórást mutatnak. Lange és Fratczak (2010: 104) számításai szerint például 2007-ben a 3-6 éves gyermekek 48\%-a kapott óvodai ellátást, miközben 2004-ben a 6 éves gyermekek 98\%-a vett részt iskola-előkészítői oktatásban (ami szintén az óvodában folyik). A szerzőpáros további adatai szerint a 2007/2008-as tanévben a 3-5 éves gyermekek 47\%-a részesült óvodai ellátásban. A Polish Eurodyce Unit mérései azt közlik, hogy 1998-ban a 4 éves gyermekek 28, 2009-ben 53,

\footnotetext{
21 http://stat.gov.pl/files/gfx/portalinformacyjny/en/defaultaktualnosci/3316/9/8/1/poland_in_figures_2017.pdf Letöltés: 2018. január 15.

22 A jelzettnél is bonyolultabb és összetettebb számítási módszertani nehézségek valamennyi vizsgált ország óvodarendszerei kapcsán felmerülnek. Az óvodai hozzáférést a statisztikai hivatalok és a szaktárcák általában különböző mutatókat használva számítják ki (az iskolába lépők között az óvodába jártak aránya, az ellátásra jogosultak és a férőhelyek aránya, az óvodások és az óvodáskorú népesség aránya stb.). A leghagyományosabb hozzáférési mutató - az óvodások aránya az óvodáskorú népesség százalékában - kiszámítása és ellenőrzése is komoly gondot jelenthet, ha a szóban forgó adatot nem naptári években, hanem tanévek szerint számolják, miközben az életkori bontásokban megadott demográfiai adatok általában december 31-i vagy január 1-i állapotokat közölnek.
} 
2014-ben 71\%-a járt óvodába. ${ }^{23}$ Az Európai Bizottság 2016-os Education and Training Monitor - Poland címü jelentése szerint a 4-6 éves gyermekek óvodalátogatási aránya 2012-ben 83, 2014-ben 87 (EU-átlag 94\%), 2015-ben 90\% volt. Ugyanebben az évben a 3 évesek 70, míg az 5 évesek 97\%-a vett részt óvodai ellátásban. ${ }^{24}$

A 2007-es oktatási törvény értelmében az elöirásoknak való megfelelés esetén lényegében bármilyen jogi vagy természetes személy alapíthat óvodát vagy egyéb iskola-előkészítő intézményt, amely egy tipikus laissez-faire szabályozásnak számít. A magánbölcsődékkel ellentétben a magánóvodák jogosultak állami támogatásra, amelyet a helyi önkormányzat utal ki. Az állami óvodák dijjszabásait a helyi önkormányzat állapítja meg. A dijjak javarészt a gyermekek étkeztetését fedezik, illetve idősebb gyermekek esetében bizonyos egyéb elfoglaltságokat (például zeneórák, táncórák, logopédiai képzések) a szülők különböző mértékekben térítenek. A rendszerváltást követően az óvodai dijak folyamatosan növekedtek, elsősorban az intézmények emelkedő működési költségei miatt. A legszegényebb családok számára az önkormányzat általában mérsékli az óvodai dijakat, esetleg teljesen el is engedi azokat (Lange-Fratzak 2010: 103). ${ }^{25}$ Mivel az önkormányzati óvodák relatíve drágának számítanak, és a férőhelyek száma is messze elmarad az igényektől, Lengyelországban magas a magánintézményekbe járó gyermekek száma (10,4\%, míg Csehországban 1,4, Szlovákiában pedig 1,7\%) (Saxonberg 2014: 64).

A lengyel óvodai (és a sokkal szükebb körü bölcsődei) ellátás körül rengeteg a feszültség. A gyermekjogi ombudsman hivatalába érkező panaszok döntő többségét az teszi ki, hogy az önkormányzati intézmény elutasította az olyan gyermek fogadását, akinek mindkét szülője teljes állásban dolgozik. Az intézmények nyitva tartása sem követi feltétlenül a szülői igényeket, ezen a PiS kormányzat már 2007-ben is igyekezett változtatni. Az állami-önkormányzati intézmények dijszabásainak köszönhetően rengeteg alacsonyabb jövedelmű család mond le a gyermekgondozási szolgáltatások igénybevételéről (Saxonberg [2014: 64] számításai szerint a 2000-es évek első felében az óvodai ellátás különböző dijai az átlag női kereset 19-20\%-át tették ki, ami rendkivül magas arány).

A 2015-ben hivatalba lépett PiS-kormány az egy óvodás gyermekre eső éves támogatási összeget 2016-ban 1300-ról 1370 zlotyra emelte, míg a 2017-es ter-

\footnotetext{
${ }^{23}$ http://eurydice.org.pl/wp-content/uploads/2016/01/BRIEF_EN_FINAL2015.pdf Letöltés: 2018. január 15.

24 https://ec.europa.eu/education/sites/education/files/monitor2016-pl en.pdf Letöltés: 2018. január 15.

${ }^{25}$ Saxonberg (2014: 63) számításai szerint 2013-ban a szegény családok óvodai ellátásban részesülő gyermekeinek körülbelül 20\%-a kapott valamilyen dijmérséklést vagy teljes elengedést.
} 
vek szerint az óvodákban nyújtott kötelező iskola-előkészítő oktatások támogatását a következő évtől 1370 zlotyiról 4300 zlotyira fogják emelni. ${ }^{26}$ A 2016ban elfogadott Maluch (tipegő kisgyermek) program a következő költségvetési évre 151 millió zlotyit különít el kimondottan a 3-4 évesnél fiatalabb gyermekek gondozásának fejlesztésére, amelynek keretében a kormány a privát bölcsődék, óvodák és gyermekklubok alapítását kívánja ösztönözni. ${ }^{27}$

\section{CSALÁDPOLITIKAI INTÉZKEDÉSEK CSEHORSZÁGBAN 1990-TÖL NAPJAINKIG}

A lengyelnél lényegesen fejlettebb csehszlovák jóléti állam a szocializmus időszakában egyszerre biztosított a családok számára kiterjedt gyermekgondozási szolgáltatásokat, illetve nagyvonalú pénzügyi támogatásokat, különösen a különböző pótlékjellegủ juttatások formájában. Az 1980-as évek végén Csehszlovákia az éves GDP-je körülbelül 4,4\%-át fordította családpolitikai kiadásokra (Steinhilber 2005: 7). A szilárdabb alapok a rendszerváltás után is éreztették hatásukat, a lengyelnél lényegesen kevésbé eladósodott, jobb makrogazdasági helyzetben lévő csehszlovák állam (még bizonyos megszorítások ellenére is) képes volt kiterjedtebb támogatást biztosítani a családoknak. Csehország és Szlovákia 1992-es különválása után az intézményes struktúrák meghatározó szerepe különösen jól demonstrálható a két ország családpolitikai modelljeinek alakulásán keresztül. A két állam eltérő politikai és társadalmi viszonyai ellenére a családtámogatási modellek sok szempontból hasonlóak maradtak.

Az 1990-es évek első felében a cseh(szlovák) családtámogatási rendszer kétlépcsős volt, amely alapjaiban mind a mai napig megmaradt. Az anyasági szabadságot a terhesség és az anyaság időszakában az anyasági támogatás (vyrovnávaci príspěvek $v$ těhotenství a mateřstvi) egészíti ki, majd a gyermeknevelés későbbi időszakában az átalánydijas szülői támogatást különböző családi/ gyermeknevelési pótlék jellegủ (rodičovský příspěvek, př́davek na dítě) juttatások kísérik. Miközben a kizárólag az édesanyák által igényelhető anyasági támogatások sokat nem változtak az évtizedek alatt, a szülői szabadság hossza és kifizetési mechanizmusai többször is átalakultak (Haskova-Uhde 2009: 101).

Csehszlovákia szétválása után a cseh jóléti állam átfogó reformjára 1995ben került sor, amikor a különböző formájú családtámogatások „állami szociális

\footnotetext{
${ }^{26}$ https://ec.europa.eu/education/sites/education/files/monitor2016-pl_en.pdf Letöltés: 2018. január 15.

27 https://ec.europa.eu/education/sites/education/files/monitor2016-pl_en.pdf Letöltés: 2018. január 15.
} 
támogatássá” minősültek át, amelyek elosztása a helyi hatóságok feladata lett. A reform számos támogatási formát jövedelemteszteltté alakított, ugyanakkor a kritériumok nem lettek különösebben korlátozó módon megállapítva. Mindemellett fontos megjegyezni, hogy az 1990-es évek közepére a cseh családtámogatási paradigmában háttérbe szorult a gyermekvállalás állami eszközökkel történő ösztönzése, a családpolitika egyre inkább a társadalmi egyenlőtlenségeket és a szegénység újratermelését megelőzendő szociálpolitikává vált (Frejka-GietelBasten 2016: 25). A liberál-konzervatív Demokratikus Polgári Párt (Občanská demokratická strana, ODS) 1995-ös családtámogatási reformprogramja alapvetően két fő célt szolgált. Egyrészt a kormány a jövedelmi viszonyokhoz kívánta kötni az anyasági támogatást, amely ezáltal csak a legszegényebb családok számára vált volna elérhetővé. Ezt a törekvést azonban az erős kereszténydemokrata ellenzék (Křestanská a demokratická unie - Československá strana lidová, KDU-ČSL) megakadályozta, miközben népesedésügyi szakemberek a javaslat negatív demográfiai hatásaitól tartottak (Saxonberg 2014: 235).

Az 1995-ös családtámogatási reform körüli politikai csatározások egy olyan kompromisszummal zárultak, amely mind a mai napig meghatározza a pénzügyi támogatások rendszerét. Az ODS keresztülvitte a gyermeknevelési pótlék kifizetésének jövedelemteszthez való kötését, viszont a négy évig igényelhető szülői szabadság idején folyósított átalánydíjas támogatás univerzális jelleggel jár mindenkinek. A kereszténydemokraták pedig végül elérték a 4 éves kiterjesztést, igaz nem anyasági, hanem mindkét szülő számára igénybe vehető gyermekgondozási szabadság formájában. A reformból ugyanakkor kimaradtak azok a KDU-ČSL javaslatok, amelyek arra kötelezték volna a munkaadókat, hogy a 4 éves szülői szabadság után visszavegyék a munkavállalókat. A kötelező visszafoglalkoztatás időszaka továbbra is három év maradt, amely a reform előtti gyermeknevelési szabadság hosszához igazodott (Saxonberg 2014: 236). A támogatási rendszer viszont komoly diszkrepanciákat okozott a gyermekek óvodába történő felvétele kapcsán; mivel az állami intézmények csak szeptemberben fogadják a frissen óvodába kerülő gyermekeket, az otthon maradó anyák sokszor túllépik a három évet, amíg a munkavállalónak törvényi kötelezettsége őt visszafoglalkoztatni (Haskova-Uhde 2009: 104). A munkaerőpiaci diszkrepanciák ellenére a hosszú szülői szabadság intézménye népszerűnek számít, ugyanakkor problémásnak mondható, hogy döntő többségben kizárólag nők veszik igénybe. A Cseh Statisztikai Hivatal (Český statistický úřad, Čsú) adatai szerint az anyák körülbelül negyede marad otthon három évnél tovább, míg 40\%-uk 2-3 évet tölt otthon a gyermekkel. Ezzel összefüggésben viszont növekedett a 
szülőképes korú nők munkanélküliségi rátája, a kisgyermekes anyák a munkaerőpiac leginkább veszélyeztetett szegmentumának számítanak (részben a hosszú szabadság miatti stigmatizációknak, részben a túlzottan merev foglalkoztatási kondícióknak köszönhetően) (Haskova-Uhde 2009: 105).

A cseh családtámogatási modell jelentős megszorítássorozaton esett át a 2000-es évek második felében. Ennek oka elsősorban a válság, illetve a kormányok deficitcsökkentési törekvései voltak. Ezek az átalakítások lényegesen szükitették a juttatásokra jogosultak körét. A 2006 utáni kormányok családpolitikai koncepcióit az egyéni felelősség és az állami ellátórendszertől való függőség lazításának hangsúlyozása hatotta át. A 2010-es választások után a jobbközépszociáldemokrata koalíciós kormány idején ez a retorika még kiegészült a jóléti támogatásokat „túlzott mértékben” igénybevevők stigmatizálásával és a gyermekgondozási támogatások elosztásának nagyobb hatékonyságával. 2008-ban a jobbközép kormány a 4 éves korig igénybe vehető gyermekgondozási támogatás átalakitását szorgalmazta. A javaslat lényege az volt, hogy a szülők eldönthetik, hogy rövidebb időszakot töltenek otthon magasabb átalánytámogatás mellett, vagy hosszabb időt alacsonyabb juttatásokkal (a pénzügyi támogatások rendszere ma is így müködik, lásd lentebb). A juttatások megvágása a kormány költségvetési céljait szolgálta, és elsősorban az alacsonyabb jövedelmü anyákat ösztönözte a hosszabb otthonmaradásra. 2010-ben az ODS-CSSD-kormány csökkentette az egyszeri szülési támogatás (přídavek na ditě) összegét is, illetve kizárták a kifizetésekből a munkanélküli nőket (Blum et al. 2014: 479). Ezzel egyidőben a szülési támogatást jövedelmi szinthez kötötték, és már csak az első gyermek után folyósították. A Čsú számításai szerint ez az intézkedés 80\%-kal csökkentette a szülési támogatási kiadásokat (Frejka-Gietal-Basten 2016: 25).

2009-2010-ben a kormány 7 hetes kortól az apák számára is elérhetővé tette a szülési szabadságot, viszont csökkentette az egyedülálló anyák számára nyújtott gyermeknevelési pótlék összegét, amivel elsősorban a házasságon kívül született gyermekek relatíve magas számát kivánta csökkenteni. Ez a megszorítás azonban rendkívül hátrányosan érintette a gyermekeiket egyedül nevelő anyákat, akik egy egyébként is sérülékeny szegmentumát jelentik a munkaerőpiacnak. 2012-ben a kormány jelentősen átalakította a szociális pótlék elnevezésű juttatást. Ez a támogatási forma az alacsony jövedelmű családok számára nyújtott segítséget a gyermeknevelési költségek fedezésében, és a kifizetések mértéke a család jövedelmi helyzetéhez volt kötve. Az átalakítás után csak a fogyatékos gyermekeket nevelő szülők lettek jogosultak a támogatás igénylésére (Blum et al. 2014: 480). 


\section{PÉNZBELI ELLÁTÁSOK}

\section{Gyermeknevelési szabadságok}

Csehországban a fizetett anyasági és szülői szabadságok, a kiterjedt pótlékjellegű kifizetések, illetve a különböző egyszeri juttatások jóval összetettebb és összefüggőbb rendszert alkotnak, mint például Lengyelország esetében, így az egyes támogatási formák szétválasztása inkább csak metodikai jellegü. ${ }^{28} \mathrm{~A}$ fizetett terhességi és anyasági szabadság egy gyermek születése esetén 28 hétig, ikerszülés esetén 37 hétig jár az édesanyának. A szabadság a szülés tervezett időpontjától visszaszámított 6-8 héttel kezdhető meg (Kocourková 2017: 1). Halva születés esetében 14 hét szabadság biztositott. Az apák a születés utáni 7. héttől kezdve igényelhetnek fizetett apasági szabadságot, de minimum 14 hetet az anyának kötelezően ki kell vennie. ${ }^{29} \mathrm{~A}$ szimpla anyasági támogatás (peněžitá pomoc $v$ mateřství) normál esetben az anya nettó fizetésének 70\%-át teszi ki, és az állam a társadalombiztosítási alapból fizeti. ${ }^{30} \mathrm{~A}$ juttatás igénylésének feltétele a társadalombiztosítási járulékok fizetése az igénylést megelőző minimum 270 napban (egyéni vállalkozó esetében 180 napban). ${ }^{31}$ Bizonyos esetekben viszont életbe lép egy jóval bonyolultabb helyettesítési mechanizmus is. Az ún. kompenzációs terhességi és anyasági támogatást (vyrovnávaci príspěvek $v$ těhotenstvi a mateřstvi) akkor fizeti az állam, ha az anyát a szülési szabadság miatt a munkaadója alacsonyabb fizetési fokozatba sorolja, vagy kénytelen munkahelyet váltani. Ilyen esetekben a juttatások alapját a szülő új pozíciójában keresett napi szintre bontott jövedelemnagysága jelenti. ${ }^{32} 942$ cseh korona napi keresetig a jövedelemhelyettesítési ráta 100\%-os, 942 és 1412 korona között

\footnotetext{
${ }^{28}$ Ahogy a cseh családtámogatási rendszer pénzbeli támogatásainak elemzése során is egyértelmủ lesz, az anyasági és szülöi szabadsághoz kapcsolódó juttatások, illetve a családi pótlék jellegủ támogatások között sok szempontból nem érdemes éles különbséget tenni. A leglényegesebb különbségek részben triviális jellemzőket jelentenek: a szülési/szülői juttatások a terhességi és gyermekgondozási szabadságok miatt kieső munkabért kompenzálják, míg a családi pótlékszerủ kifizetések a gyermek felneveléséhez szükséges kiadások kompenzációjához járulnak hozzá, és alaphelyzetben nem implikálnak szabadságolási kérdéseket. Másrészt a különbségek abból is adódhatnak (például Lengyelország esetében), hogy a kétféle támogatási forma finanszirrozása különböző bevételekből és kasszákból történik.

$29 \mathrm{http}: / /$ ec.europa.eu/employment_social/empl_portal/SSRinEU/Your\%20social\%20security\%20rights\%20in\%20Czech\%20 Republic_en.pdf (2013: 11) ; http://ec.europa.eu/social/main.jsp?catld=1106\&intPageld=4469\&langld=en Letöltés: 2018. január 15.

30 2008-ban a cseh kormány a kompenzációs arányt az anya bruttó fizetésének 90\%-áról a nettó fizetés 69\%-ára változtatta (jelenleg az érték 70\%). Saxonberg és Sirovátka (2009: 97) számításai szerint az átalakitás azt eredményezte, hogy az anyasági támogatás a bruttó fizetés körülbelül 80\%-át teszi ki, vagyis összességében valamelyest csökkent a kifizetések összege.

${ }^{31}$ https://www.mpsv.cz/files/clanky/6600/information_family_policy.pdf Letöltés: 2018. január 15.

${ }^{32} \mathrm{~A}$ kompenzációs terhességi és anyasági támogatás iránti kérelmet az édesanya a munkáltatójával együtt nyújtja be. Vitás esetekben a Cseh Társadalombiztosítási Hivatal (Česká správa sociálního zabezpečeni) jár el.
} 
60\%-os, 1412 és 2824 korona között 30\%-os, 2824 korona feletti kereset esetén pedig az édesanya nem jogosult erre a támogatási formára. ${ }^{33}$

A gyermek 4 éves koráig vehető igénybe szülői szabadság, illetve az ezen időszak alatt folyósított szülői pótlék (rodičovský příspěvek). Ahogyan azt fentebb is jeleztük, a gyermekgondozási szabadság alatti támogatás hosszáról és intenzitásáról a szülők döntenek. A juttatások összege a szabadság hosszával párhuzamosan csökken. ${ }^{34} \mathrm{Ha}$ a szülők 19 hónapig kívánják igénybe venni a szülői pótlékot, akkor 11500 cseh korona támogatást kapnak. 29 hónap esetében 7600, ezen túl pedig 5116 koronát. ${ }^{35}$ Beteg gyermek esetében a pótlék összege fix 7600 korona a gyermek 7 éves koráig. A legrövidebb ideig tartó és legmagasabb juttatást igénylő szülők esetében a támogatás folyósítása 2012 óta a napi keresethez mért jövedelemteszthez kötött. Azon szülők esetében, akiknél a napi keresetre bontott jövedelemteszt nem végezhető el (egyetemi hallgatók, önálló vállalkozók, vagy bárki, aki valamilyen okból nem fizetett társadalombiztositást), a szülői pótlék kifizetése egyféle mechanizmus alapján történik: 9 hónapig havi 7600 koronát kapnak, majd 9 hónaptól 4 éves korig havi 3800 koronát (Blum et al. 2014: 478). ${ }^{36}$ Megszorítások vannak viszont érvényben a gyermekgondozási intézmények igénybevétele esetén. A támogatás csak akkor folyósitható, ha a gyermek nincs napi négy óránál többet az óvodában, illetve 2 éves kor alatt a gyermekek maximum 46 órát vagy öt napot lehetnek bölcsődében havonta (Blum et al. 2014: 480).

A gyermek 6 éves koráig vehetik igénybe a rászoruló szülők a jövedelemteszthez kötött gyermeknevelési pótlékot (prrídavek na dítě). A jövedelemküszöb, amely alatt a családok jogosultak a kifizetésre a létminimum 2,4-szeresében van megállapítva. A megélhetési minimum összegét a Čsú külön számítja ki az egy háztartásban élő személyekre (lásd: 2 . táblázat), és ezek összege adja a teljes megélhetési minimumot, amelynek a 2,4-szeres értéke alatt vehető igénybe a gyermeknevelési pótlék, életkor szerinti bontásban. A cseh munkaügyi és szociális minisztérium adatai szerint a rászorultsági kritérium alatti családoknak a 6 év alatti gyermek után 500, a 6-15 év közötti gyermek után 610, a 15-26 év közötti gyermek után pedig 700 cseh korona jár havonta. ${ }^{37}$

\footnotetext{
33 http://ec.europa.eu/social/main.jsp?catld=1106\&intPageld=4469\&langld=en Letöltés: 2018. január 15.

34 2017-ben a kormány lényegesen csökkentette a szülői szabadság igénybe vehető időtartamait. 24, 36, illetve 48 hónapról 19, 29, illetve 43 hónapra rövidült a fizetett szabadság.

${ }^{35}$ A szülői szabadság alatt kifizetett juttatások összege 220 ezer cseh koronában van maximalizálva a gyermek 4 éves koráig. http://ec.europa.eu/social/main.jsp?catld=1106\&intPageld=4469\&langld=en Letöltés: 2018. január 15.

${ }^{36} \mathrm{http}: / /$ ec.europa.eu/social/main.jsp?catld=1106\&intPageld=4469\&langld=en Letöltés: 2018. január 15.

37 http://www.mpsv.cz/en/1603 Letöltés: 2018. január 15.
} 
2. táblázat: A családi háztartásban egy före jutó megélhetési minimumösszegek2017-ben (cseh korona) The per capita minimum of subsistence in family households in the Czech Republic (CZK) in 2017

\begin{tabular}{lc}
\multicolumn{1}{c}{ Megnevezés } & Megélhetési minimumösszeg \\
\hline Elsődleges felnőtt korú kereső a háztartásban & 3140 \\
Második felnőtt korú kereső a családban (nem kiskorú) & 2830 \\
6 év alatti eltartott gyermek & 1740 \\
6-15 év közötti eltartott gyermek & 2140 \\
15-26 év közötti eltartott, tanuló gyermek & 2450
\end{tabular}

Forrás: http://ec.europa.eu/social/main.jsp?catld=1106\&intPageld=4469\&langld=en Letöltés: 2018. január 15.

Az ún. szociális támogatás igénylését a kormány 2012-ben előbb jelentősen korlátozta a tartósan beteg gyermeket nevelő családokra, majd teljesen meg is szüntette ezt a juttatási formát, mégis érdemes röviden áttekinteni a múködési mechanizmusát, mivel a támogatás kivezetése rendkívül hátrányosan érintette a szegényebb családokat (Blum et al. 2014: 480). A juttatást azon családok kaphatták, ahol az összes jövedelem nem haladta meg az eltartott gyermekekre számított megélhetési minimum összegek kétszeresét. Az egy főre bontott létminimum összege itt csak a gyermekek korának függvényében változott, a szülőkre eső háztartáson belüli jövedelem mértéke nem számított (Blum et al. 2014: 478). A szociális támogatás mértéke növekedett, ha a családban tartósan beteg gyermeket neveltek, vagy ha a szülő egyedül nevelte a gyermekét.

\section{Családi adókedvezmények}

A cseh állam családi adókedvezmény-rendszerrel is próbálja segíteni a gyermeket vállalók helyzetét. Az adókedvezmények rendszere szerves része egy állam jóléti politikájának, és vagy az adóalapból, vagy magából az adóból történő levonást jelent. A családi adókedvezmények fő célja egyrészt a gyermekvállaláshoz kapcsolódó magasabb költségek ellensúlyozása különböző redisztributív mechanizmusokon keresztül, másrészt a szülők munkavégzésének ösztönzése és támogatása. A családi adókedvezmények müködése és hatékonysága kapcsán az egyik fö kérdés, hogy a rendszer milyen intenzitású redisztributív hatással és munkavállalásra gyakorolt hatással rendelkezik. Megfelelő ellensúlyok hiányában az adókedvezmények könnyen vezethetnek „felfelé történő, vagy »perverz« új- 
raelosztáshoz", hiszen a nagyobb kedvezményekhez csak a megfelelően magas jövedelmúek jutnak hozzá (Darvas-Mózer 2004: 68).

A cseh családi adókedvezmény rendszerében a megtéritendő adójóváirás összege 2008-ban 6000-ről 10680 cseh koronára emelkedett gyermekenként. A visszatérithető adójóváirás bevételnek számít, amelyet belevesznek a háztartási jövedelmek számításába, ezáltal befolyásolja például az egyéb családtámogatási juttatásokra való jogosultságot. Bizonyos esetekben viszont az adójóváirás nem speciálisan visszatéríthető módon müködik (credit supplemented tax bonus, CTB), ami negatív adóként funkcionálva védi azokat a családokat, amelyeket az alacsony jövedelem részlegesen vagy teljesen kirekeszt az adókedvezmény érvényesítéséből. A 2011 óta elérhető speciálisan visszatérithető adókedvezményt (amelyet nem számítanak bele háztartási jövedelmekbe) csak azok a családok vehetik igénybe, ahol a jövedelem nem haladja meg az éves minimálbér hatszorosát. A CTB maximalizált értéke 52200 cseh korona, ami az egy gyermek esetén járó visszatérithető adójóváirásnak a 4,9-szerese (Jahoda-Jana 2013: 2214).

A cseh családi adókedvezmény-rendszer redisztributív és szegénységcsökkentő hatásait illetően nincs szakirodalmi konszenzus. Jahoda és Jana (2013: 2219) szerint a mechanizmus redisztribúciós potenciálja meglehetősen gyenge, mivel a (jövedelemteszt ellenére) a kedvezményezettek 80\%-a nem tekinthető valóban rászorultnak. A szerzőpáros számításai azt mutatják, hogy az adókedvezményt igénylő háztartások 23-25\%-át fenyegeti szegénység, miközben ez a réteg az összes kifizetés mindössze 20\%-át kapja. A CTB gyakorlatilag a társadalom valamennyi decilise számára elérhető (beleértve a legmagasabb decilisekbe tartozó családokat), aminek elsősorban az az oka, hogy a kedvezmény mértékét az igénylő jövedelméhez mérten, nem pedig a teljes családi jövedelemhez viszonyítva tesztelik. Emiatt általában az alacsonyabb jövedelmú szülő (az esetek döntő többségében az anya) igényli meg az adókedvezményt, mivel a magasabb jövedelem ellenében történő jövedelemteszt esetén a család valószínűleg elesne a támogatástól. Ez a mechanizmus viszont nem szüri ki azt a lehetőséget, hogy az apa magasabb keresete miatt a háztartásban az egy före eső jövedelem is magas lesz, viszont a család az anya igénylése miatt ugyanúgy jogosult a kedvezményre (Jahoda-Jana 2013: 2219).

Avram és Militaru (2016: 1374) ugyanakkor arra hívja fel a figyelmet, hogy a cseh gyermekszegénységi mutatók európai szinten is jónak mondhatók, amiben jelentős szerepe van a családi adókedvezmény-rendszernek. A szerzőpáros szerint a különböző családtámogatási mechanizmusoknak köszönhetően (amelyben az adókedvezmény mellett az egyéb kifizetések és támogatások is 
benne vannak) a gyermekszegénységi ráta a transzferek után 17,6-ről 9,6\%-ra esik a mediánjövedelem 60\%-ával rendelkező családokban, míg a mediánjövedelem 40\%-át kereső családokban ugyanez az arány 9,3, illetve 1,5\%. A szerzők azt is hangsúlyozzák, hogy nemzetközi összevetésben a cseh családi adókedvezmény-rendszer hatása a gyermekszegénység enyhítése kapcsán meglehetősen robosztusnak tűnik, vagyis ennek az intézkedésnek relative nagy önsúlya van a családtámogatási intézkedéscsomagban (ami egyben azt is jelenti, hogy a családi adókedvezményekkel összevetve az egyéb intézkedéselemeknek kisebb szerep jut a gyermekszegénység csökkentésében).

\section{GYERMEKGONDOZÁSI SZOLGÁLTATÁSOK}

\section{Bö/csődei ellátás}

A rendszerváltás után Csehországban radikálisan csökkent az állami fenntartású bölcsődék (jes/e) száma. A zuhanás olyan mértékű volt, hogy a bölcsődei ellátás tekintetében a szocializmus vége felé még a világ élvonalába tartozó országban az 1990-es évek közepére lényegében alig maradt valami az állami bölcsődei rendszerből. Haskova (2010: 14) szerint ez a tendencia a költségvetési megszorításokon túl az 1990-es évek konzervatív családpolitikai narratívájával függött össze. Az évtized során előtérbe kerülő re-familizáló családpolitikák felértékelték a nő gondozói szerepét, amelynek legeklatánsabb megnyilvánulása a négy évig igénybe vehető szülői szabadság volt. Mindehhez járult még a szocialista nagyvállalatok által működtetetett bölcsődék gyors eltűnése és a bölcsődei finanszírozás önkormányzati fennhatóság alá kerülése (Haskova 2010: 14). Ez utóbbi azt jelentette, hogy a bölcsődék finanszírozását teljes egészében a helyi önkormányzatnak kellett megoldania, viszont az óvodákkal ellentétben a bölcsődék után semmiIyen kiegészítő állami támogatás nem járt. Az intézmények működési költségeinek fedezése ezáltal az önkormányzat, illetve a szülők feladatává vált, miközben a bölcsődék egy 1991-es törvénynek köszönhetően kikerültek az iskola-előkészítő intézmények köréből (ahová egyébként csak néhány évvel korábban kerültek be). Ezek a folyamatok az 1990-es években tömeges bezárásokhoz vezettek (lásd: 3. táblázat). 1991-ben még 1043 állami bölcsőde és 39829 férőhely volt Csehországban, míg 2007-re már csak 54 intézmény müködött mindössze 1587 férőhellyel, amelyek döntő többsége a nagyvárosi igényeket szolgálta ki (Válková 2010: 43). Tovább bonyolítja a helyzetet, hogy a bölcsődei helyek egy részét azok a gyermekek foglalják el, akik a szülői szabadságon lévő szülők havi öt bölcsődei napban maximalizált szolgáltatását veszik igénybe. 
3. táblázat: Önkormányzati bölcsődék és bölcsődei férőhelyek száma Csehországban Number of municipial nurseries and their places for children in the Czech Republic

\begin{tabular}{|c|c|c|c|c|c|c|c|c|}
\hline Megnevezés & 1990 & 1992 & 1996 & 1997 & 2000 & 2003 & 2005 & 2008 \\
\hline Intézmények száma & 1043 & 381 & 151 & 101 & 65 & 60 & 54 & 48 \\
\hline Bölcsődei férőhelyek & 39829 & 13196 & 5551 & 2965 & 1867 & 1770 & 1671 & 1498 \\
\hline Időtartam & - & 1990-92 & $1992-96$ & 1996-97 & 1997-00 & 2000-03 & $2003-05$ & $2005-08$ \\
\hline $\begin{array}{l}\text { Férőhelyek számának } \\
\text { csökkenése, \% }\end{array}$ & - & $-64,9$ & $-57,9$ & $-46,6$ & $-37,0$ & $-5,2$ & $-5,6$ & $-10,4$ \\
\hline
\end{tabular}

Forrás: Kucharová (2010: 36) alapján saját szerkesztés.

A bölcsődébe járó gyermekek döntő többsége (több mint a fele) 2-3 éves, körülbelül a negyedük 3 évnél idősebb vagy 1-2 éves. Elenyésző viszont az egy évnél fiatalabb gyermekek aránya. Ez azt mutatja, hogy a legnagyobb igény azoknál a szülőknél jelentkezik, akik a legrövidebb, 19 hónapos fizetett szülői szabadságot igénybe véve a gyermek 2 éves kora után szeretnének visszatérni a munkaerőpiacra (Válková 2010: 43).

Az állami bölcsődék bezárási hullámára ráerősítettek még a demográfiai tendenciák is. Az 1990-es évek demográfiai mélypontja miatt hirtelen jelentősen csökkent a bölcsődei férőhelyek iránti igény. A Čsú adatai szerint a 2 év alatti gyermekek összlétszáma az 1993-as 369 ezerről 2002-re 273 ezerre zuhant, a 3-5 év közötti gyermekek összlétszáma pedig 383 ezerről 286 ezerre (Kucharová 2010: 24). A bölcsődei kapacitások szükössége a 2000-es évek közepére, második felére vált nyilvánvalóvá, amikor az ezredforduló idején növekedésnek induló születésszám ismét növelni kezdte az igényeket. 2007-ben 323 ezer, 2008-ban pedig már 341 ezer 2 év alatti, illetve 267 ezer, valamint 296 ezer 3-5 év közötti gyermek élt Csehországban (Kucharová 2010: 24).

A radikálisan lecsökkent kapacitású állami bölcsődei rendszer viszont nyilvánvalóan képtelen volt felszívni a megnövekedett gyermekmennyiséget, ezért a 2000-es években két irányból indult meg a hirtelen erősödő igények kielégitése. Egyrészt az állam lehetővé tette, hogy (jelentős diszkrecionális jogkör mellett) ${ }^{38}$ az óvodák is befogadhassanak 3 év alatti gyermekeket. Ennek köszönhetően a 2 éves gyermekek közel negyede van óvodai férőhelyre regisztrálva, miközben folyamatosan nő az egyre túlterheltebb óvodák által elutasí-

\footnotetext{
${ }^{38}$ A 3 év alatti gyermek elfogadása kapcsán az intézmény mindenekelőtt a szülők anyagi helyzetét és a szabad férőhelyek számát mérlegelve dönt az esetleges elhelyezés mellett.
} 
tott regisztrációs igények száma is. A túl sok gyermeket fogadó óvodák sokszor úgy próbálják megoldani a helyzetet, hogy évkezdéskor beregisztrálják ugyan a 3 évesnél fiatalabb gyermekeket, valójában viszont csak akkor adnak nekik férőhelyet, amikor a gyermek betöltötte a 3. életévét, feltöltve ezáltal az időközben kirotálódott gyermekek helyét. Másrészt megjelentek a privát bölcsődék is, és kezd elterjedni a gyermekfelvigyázás is, ám mind a magánintézmények, mind a babysitterek megfizetése meghaladja az átlagos jövedelmű cseh családok lehetőségeit. ${ }^{39}$ A cseh kormány ugyanakkor nem ad túlzottan sok segítséget a magánbölcsődék fenntartásához, miközben különösen a 2000-es években rengeteg magánintézmény jött létre. A magánbölcsődék térítési díjai rendkívül magasak (jóval meghaladják a nettó havi átlagkereset felét), ami csak a társadalom legfelsőbb rétegei számára teszi lehetővé a privát intézmények igénybevételét (Saxonberg 2014: 63).

Mivel a szülői szabadságról visszatérő nőt a munkaadója csak három évig köteles visszafoglalkoztatni, a gyermekgondozási helyek szűkössége oda vezet, hogy az anyák közel 40\%-a a harmadik év letelte után nem tud visszamenni dolgozni, mivel csak a negyedik évbe belenyúló szabadság igénybevételével tudja megoldani gyermeke felvigyázását. Ezzel viszont kikerülnek a kötelező visszafoglalkoztatás védett időszakából, ami jelentősen megnehezíti a munkaerőpiaci reintegrációjukat. Mindezek eredményeként a középfokú végzettséggel rendelkező nők körülbelül 80, míg a diplomás nők közel 70\%-a marad otthon 1-3 éves gyermekével, és a szükös gyermekgondozási férőhelyek miatt sokan belekezdenek a szülői szabadság negyedik évébe is (Haskova 2010: 16).

\section{Óvodai ellátás}

A cseh óvodarendszer nem élt át a bölcsődei hálózathoz hasonló mértékű összeomlást a rendszerváltás után, bár az állami intézmények és férőhelyek száma ezen a területen is csökkent. 1991-ben 7335 óvoda (mateřské školy) volt Csehországban, 2008-ban már csak 4808. A demográfiai hatások az óvodáskorú népesség esetében is hasonlóan müködtek, mint a 3 év alatti gyermeknél, ami nagyjából hasonló megpróbáltatásokat rótt az intézményrendszerre (vö. 4. táblázat).

\footnotetext{
39 Information about family policy system in the Czech Republic (2009). https://www.mpsv.cz/files/clanky/6600/ information_family_policy.pdf. Letöltés: 2018. január 15.
} 
4. táblázat: Óvodák száma Csehországban

Number of kindergartens in the Czech Republic

\begin{tabular}{|c|c|c|c|c|c|c|c|c|}
\hline Megnevezés & $\begin{array}{c}1989 / \\
90\end{array}$ & $\begin{array}{c}1991 / \\
92\end{array}$ & $\begin{array}{c}1995 / \\
96\end{array}$ & $\begin{array}{l}1999 / \\
2000\end{array}$ & $\begin{array}{c}2002 / \\
03\end{array}$ & $\begin{array}{c}2005 / \\
06\end{array}$ & $\begin{array}{c}2008 / \\
09\end{array}$ & $\begin{array}{c}2016 / \\
17\end{array}$ \\
\hline Állami óvodák & 7328 & 6906 & 6338 & 5816 & 5697 & 4741 & 4702 & 5209 \\
\hline Magánóvodák & - & 61 & 121 & 69 & 80 & 72 & 82 & - \\
\hline Egyházi óvodák & - & 5 & 16 & 16 & 21 & 21 & 25 & - \\
\hline Állami óvodák aránya,\% & 100 & 99,1 & 97,9 & 98,6 & 98,3 & 98,1 & 97,8 & - \\
\hline Gyermekek száma & 395164 & 323270 & 333433 & 290192 & 284865 & 282183 & 301620 & 362653 \\
\hline $\begin{array}{l}\text { Óvodába járó } \\
\text { gyermekek aránya } \\
\text { a 3-5 év közötti }\end{array}$ & & & & & & & & \\
\hline népességen belül, \%a) & 97,4 & 83,3 & 88,4 & 94,7 & 104,3 & 102,8 & 101,7 & - \\
\hline $\begin{array}{l}\text { Az óvodák számának } \\
\text { változása, \% }\end{array}$ & 100 & 95 & 88 & 81 & 79 & 66 & 66 & 71 \\
\hline $\begin{array}{l}\text { Az óvodába járó } \\
\text { gyermekek számának } \\
\text { változása, \% }\end{array}$ & 100 & 82 & 84 & 73 & 72 & 71 & 76 & 92 \\
\hline
\end{tabular}

Forrás: Kucharová (2010: 37), ČSÚ alapján saját szerkesztés.

Megjegyzés: a) Az arány számításakor figyelembe kell venni, hogy nemcsak 3-5 év közötti gyermekek járnak óvodába, hanem kivételes esetben 3 év alatti, illetve 5 év feletti gyermekek is. ${ }^{40}$

Az óvodai férőhelyek szükösségét ugyanakkor komolyan súlyosbítja még egy tényező. Míg a kisebb gyermekek esetén a szülők hajlamosabbak úgy gondolni, hogy a gyermeket az anyának kell gondoznia, ${ }^{41}$ addig a 4 évesnél idősebb (vagyis már óvodáskorú) gyermekek esetében a szülők 73\%-a véli úgy, hogy a gyermek legjobb helye az óvodában van (Kucharová 2010: 26). Ez az explicit módon familializáló attitűd alapjaiban határozza meg a cseh családtámogatási modell egyéb intézkedéscsomagjait. A hosszú fizetett szülői szabadságon keresztül a rendszer némileg tompítja a bölcsődék iránti igényt, az óvodai szolgáltatások iránti igény viszont magas, már csak azért is, mert a fizetett szülői szabadság maximuma a gyermek 4 éves korában ér véget. Tovább növeli az óvodai férőhelyek iránti igényeket a gyermekgondozási szolgáltatásokkal való magas fokú elégedettség. A gondozási és az óvodai tevékenységekkel a szülők 97\%-a elégedett, több mint 50\%-a pedig nagyon elégedett.

\footnotetext{
${ }^{40}$ Az Európai Bizottság Education and training monitor 2016 - Czech Republic jelentése 2015-ben 86,4\%-ra becsülte a 4-6 éves gyermekek óvodalátogatási arányát. https://ec.europa.eu/education/sites/education/files/monitor2016-cz_en.pdf Letöltés: 2018. január 15.

${ }^{41}$ Közvéleménykutatási adatokra hivatkozva Kucharová (2010: 27) ezt az arányt az 1-2 éves gyermekek esetében 90, a 2-3 éves gyermekeknél 78\%-ra becsüli.
} 
Az óvodák müködtetéséért a helyi önkormányzatok felelősek, viszont az intézmények finanszírozását (jóllehet egyre inkább csökkenő mértékben) támogatja az oktatási, ifjúsági és sportminisztérium. A növekvő fenntartási költségeket az önkormányzatok a szülőkre terhelik, amely körülbelül az egy före jutó bruttó minimálbér egytizedét jelenti. Ha a gyermek kétszülős családban él, az óvodai díj nagyságrendileg az átlagjövedelmű szülők bruttó keresetének körülbelül 2\%-át teszi ki, míg az alacsony jövedelmü családok esetében ugyanez az arány a nettó jövedelem körülbelül 8\%-át jelenti (jóllehet egyéni elbírálás útján a szegényebb családok gyakran mentesülnek a díjfizetés alól). A konkrét díjakat azonban számos tényező határozza meg, amely javarészt az önkormányzat döntésétől és az óvoda által nyújtott szolgáltatásoktól függ. Mindezek alapján elmondható, hogy a díjak valószínűleg nem bizonyulnak meghatározó szempontnak az óvodai helyekhez való hozzáférésben (Kucharová 2010: 29).

A 4-5 éves gyermekek óvodai elhelyezésére mutatkozó magas igények, az iskolába későn engedett gyermekek, illetve a bölcsőde helyett az óvodában regisztrált 3 év alatti gyermekek miatt a cseh óvodák túlterheltek, és az elutasított befogadási kérelmek száma egyre növekszik (különösen a nagyobb városokban). Nehezíti a hozzáférési mutatók meghatározását, hogy egyrészt nincs arra semmilyen központi adat, hogy országos szinten hány szabad óvodai hely marad végül kihasználatlanul (javarészt a regionális demográfiai különbségek miatt), illetve az egyedi elbírálások miatt azt sem lehet országos szinten meghatározni, hogy pontosan miIyen arányban vesznek igénybe óvodai férőhelyeket a 3 év alatti gyermekek.

\section{CSALÁDPOLITIKAI INTÉZKEDÉSEK SZLOVÁKIÁBAN 1990-TŐL NAPJAINKIG}

Csehszlovákia szétválása után az első nacionalista-populista Mečiar-kormány 1993-ban korlátozta az eltartott gyermek után járó támogatás (prídavok na dieta) mértékét: csak azok a családok lettek rá jogosultak, amelyekben a havi átlagjövedelem nem érte el a 16 ezer szlovák koronát. A kormányváltást követően a mindössze kilenc hónapig regnáló, a kereszténydemokraták által dominált nagykoalíció (amelynek magyar pártok is a tagjai voltak) tovább szigorította a gyermeknevelési pótlék jövedelmi kritériumait. 1996-ra a korábban univerzális családi pótlékra jogosult, 15 év alatti gyermeket nevelő családok aránya 78\%-ra csökkent. A második Mečiar-kormányt követő jobbközép koalíció ismét univerzálissá tette a családi pótlékot. Ezen túl külön kiegészítő gyermeknevelési pótlékforma (priplatok k prídavku na dieta) vált elérhetővé azon hátrányos 
helyzetủ családok számára, amelyek éves jövedelme alacsonyabb volt, mint a megélhetési minimum 1,37-szorosa, illetve 2,2-szerese. ${ }^{42}$ A Dzurinda-kormány 2004-ben megszüntette a gyermeknevelési pótlékkifizetések differenciálását, viszont a relatíve alacsony fixösszegü támogatás nem bizonyult elegendőnek ahhoz, hogy otthon tartsa a nőket (Saxonberg 2014: 239-240).

Amint azt Lengyelország esetében is láthattuk a jobboldali pártok Szlovákiában is igyekeztek egyrészt kiterjeszteni a családi juttatások rendszerét, másrészt ösztönözni az apák gyermeknevelésben vállalt szerepét. A 2000-es évek első felében a Szlovák Demokratikus és Keresztény Unió (Slovenská demokratická a krestáanská únia, SDKÚ) által dominált Dzurinda-kormány a szülỏi támogatást (rodičovský príspevok) elérhetővé tette az apák számára is, jóllehet a kifizetés mértéke meglehetősen alacsony volt. A 2003-ban bevezetett támogatás egyik érdekessége az volt, hogy maximum egy hónapig egyszerre vehette igénybe mindkét szülő. A mechanizmus ugyanakkor nem volt különösebben népszerü, javarészt az anyasági támogatás (materské dovolenka) alacsony helyettesítési rátájának (a kettős igénylés lehetőségének bevezetésekor a korábbi nettó fizetés 55\%-a), illetve az apáknak járó csekély átalánytámogatásának köszönhetően, ezért a kormány 2005-ben eltörölte a rendelkezést (Saxonberg 2014: 241). A Smer (Sociálna demokracia, 2005 előtt Harmadik Út), amely 2006 óta Szlovákia meghatározó pártja, igyekezett piacosítani a gyermekellátást. A kormány lehetővé tette, hogy a 3 éves szülői szabadság vége előtt a munkaerőpiacra viszszatérő szülők a ki nem fizetett szülői támogatásból finanszírozzák gyermekeik magánbölcsődei ellátását. A kezdetben nagylelkűnek tűnő 2008-as rendelkezést 2010-ben kiegészítették, amelynek értelmében a szülők már csak a meg nem igényelt szülői támogatásösszeg 25\%-át fordíthatták a privát bölcsődei ellátás finanszírozására. Mivel a magánbölcsődék díjai lényegesen magasabbak a szülői támogatás összegénél, a fel nem használt szülői támogatás negyede a magánbö|csődei költségek mindössze 8-10\%-át jelenti. Mindez nem teszi szélesebb körök számára elérhetővé a magánbölcsődei szolgáltatásokat (Saxonberg 2014: 240).

A rendszerváltást követő évtizedek családpolitikai vitái hektikusak, és pártideológiai szempontokból inkonzisztensek voltak. Például a jobbközép kormányok először szigorították a támogatások jövedelmi kritériumait, később viszont univerzálissá tették a gyermeknevelési támogatást. Az apák gyermeknevelésben betöltött szerepének növelésével szintén az egyébként konzervatív családmodell szerepét hangsúlyozó kereszténydemokrata kormányok kísérleteztek,

${ }^{42} \mathrm{~A}$ megélhetési minimum 1,37-szorosa és 2,2-szerese közti éves jövedelemmel rendelkező családok ennek a kiegészitö családi pótléknak egy csökkentett értékét kapták. 
miközben a baloldali Smer a piaci mechanizmusok szerepét igyekezett erősíteni a családtámogatási modellben.

\section{PÉNZBELI ELLÁTÁSOK}

\section{Gyermeknevelési szabadságok}

Szlovákiában a fizetett anyasági szabadság (materské dovolenka) jelenleg 34 hét, 2017. július 1-jétől 77\%-os bruttó bérhelyettesítési rátával. ${ }^{43}$ Az anyasági támogatás kiutalása a szlovák társadalombiztosítási ügynökség (Sociálna poistovňa) hatáskörébe tartozik, és az anya akkor jogosult a kifizetésre, ha az igénylést megelőző két év során legalább 270 napig fizetett társadalombiztosítási járulékot. Valamennyi társadalombiztosítási járulékot fizető anya (beleértve a magánvállalkozókat44 és az önkéntes betegbiztosítási alapba befizető nőket is) jogosult a fizetett szülői szabadságra. A fizetett anyasági szabadság 34 hetéből 6-8 hetet az édesanyának kötelező jelleggel ki kell vennie közvetlenül a szülés előtt. Ikerszülés esetén a 34 hetes fizetett anyasági szabadság 43 hétre, egyedülálló anya esetében pedig 37 hétre emelkedik. Nevelőszülők 28 hét fizetett anyasági szabadságot vehetnek igénybe, míg a legalább két újszülöttet örökbefogadó szülők 37 hetet igényelhetnek. Halvaszületés esetén az anya 14 hét fizetett szabadságra jogosult (Gerbery 2017: 352-353). Az anyasági támogatást 2003 óta az anya hozzájárulásával az apák is igényelhetik ${ }^{45}$, de az apa által használt időszakban a másik szülő nem jogosult a kifizetésre. Ezt a támogatási formát az apa a szülést követő hatodik héttől kérheti, viszont a férfiak általában magasabb fizetése miatt ez az opció sem vált kimondottan népszerűvé, jóllehet az igénylések száma növekvő tendenciát mutat (2012-ben mindössze 222 apa igényelte a szülési támogatást, 2016 -ban már 3079 [5. táblázat]). ${ }^{46}$

\footnotetext{
${ }^{43}$ https://www.eurofound.europa.eu/observatories/eurwork/articles/slovakia-incentives-for-men-to-take-time-off-work-forfamily-life Letöltés: 2018. január 15. Az anyasági támogatás összege ugyanakkor nem haladhatja meg a havi nettó átlagbér másfélszeresét (Gerbery 2017: 352).

${ }^{44}$ A szlovák társadalombiztositási rendszerben a magánvállalkozók a bevallott jövedelmük 4,4\%-át fizetik be a tb-kasszába (Gerbery 2017: 352).

${ }^{45}$ Nem összekeverendő a szintén 2003-ban bevezetett szülői támogatás (rodičovský príspevok) mindkét szülő által egyszerre igényelhető, 2005-ben megszüntetett lehetőségével.

${ }^{46}$ https://www.eurofound.europa.eu/observatories/eurwork/articles/slovakia-incentives-for-men-to-take-time-off-work-forfamily-life Letöltés: 2018. január 15. Letöltés: 2018. január 15.
} 
5. táblázat: Anyasági támogatás Szlovákiában, 2012-2016

Maternal benefits in Slovakia, 2012-2016

\begin{tabular}{lccccc}
\multicolumn{1}{c}{ Megnevezés } & 2012 & 2013 & 2014 & 2015 & 2016 \\
\hline $\begin{array}{l}\text { Támogatást igénylők összesen } \\
\text { Támogatásban részesülő férfiak } \\
\text { száma }\end{array}$ & 59548 & 58223 & 57597 & 59383 & 63937 \\
$\begin{array}{l}\text { Támogatásban részesülő férfiak } \\
\text { aránya, \% }\end{array}$ & 222 & 314 & 717 & 1731 & 3079 \\
$\begin{array}{l}\text { A támogatás átlagos időtartama } \\
\text { nők esetében, hét }\end{array}$ & 0,37 & 0,46 & 0,89 & 2,69 & 4,43 \\
$\begin{array}{l}\text { A támogatás átlagos időtartama } \\
\text { férfiak esetében, hét }\end{array}$ & 28 & 34 & 34 & 34 & 34 \\
\end{tabular}

Forrás: https://www.eurofound.europa.eu/printpdf/observatories/eurwork/articles/slovakia-incentives-for-mento-take-time-off-work-for-family-life alapján saját szerkesztés. Letöltés: 2018. január 15.

6. táblázat: Szülői támogatás Szlovákiában, 2012-2016

Parental benefits in Slovakia, 2012-2016

\begin{tabular}{|c|c|c|c|c|c|c|c|}
\hline Megnevezés & 2010 & 2011 & 2012 & 2013 & 2014 & 2015 & 2016 \\
\hline $\begin{array}{l}\text { A szülői támogatás havi } \\
\text { összege, euró }\end{array}$ & 164 & 190 & 195 & 200 & 203 & 203 & 203 \\
\hline Bruttó havi átlagbér, euró & 769 & 786 & 805 & 824 & 858 & 883 & 912 \\
\hline $\begin{array}{l}\text { A támogatás összege az } \\
\text { átlagbérhez viszonyitva, \% }\end{array}$ & 21,3 & 24,2 & 24,2 & 24,3 & 23,7 & 23,0 & 22,3 \\
\hline Összes igénylés száma & 183501 & 185393 & 188004 & 188701 & 188296 & 187228 & 187695 \\
\hline $\begin{array}{l}\text { Szülői támogatásban } \\
\text { részesülő férfiak száma }\end{array}$ & 4525 & 4803 & 5019 & 5210 & 5550 & 5710 & 5894 \\
\hline $\begin{array}{l}\text { Támogatásban részesülő } \\
\text { férfiak aránya az összes } \\
\text { támogatotton belül, \% }\end{array}$ & 2,47 & 2,59 & 2,67 & 2,76 & 2,95 & 3,05 & 3,14 \\
\hline
\end{tabular}

Forrás: https://www.eurofound.europa.eu/printpdf/observatories/eurwork/articles/slovakia-incentives-for-mento-take-time-off-work-for-family-life alapján saját szerkesztés. Letöltés: 2018. január 15.

A fizetett szülői szabadság (rodičovský príspevok) a gyermek 3 éves koráig igényelhető valamelyik szülő számára (tartós fogyatékkal rendelkező gyermek esetében 6 éves koráig). A szülői támogatás havonta fix 213 euró, és az igénylő szülő vállalhat mellette teljes állást, ha úgy dönt, hogy visszatér a régi munkahelyére, amelyet a munkaadó köteles fenntartani számára. A szlovák munkajog ugyanakkor arra is lehetőséget ad, hogy a szülő a gyermek 8 éves koráig egyhónapos részletekben vegye ki a szülői szabadságot, és a szülők váltogathatják, hogy éppen melyikük veszi igénybe a juttatást (Gerbery 2017: 353). Bár a szülői 
támogatás nettó átlagbérhez mért aránya lényegében nem változott (a juttatás összege a 2009-es 159 euróról 2017-re 213 euróra emelkedett, amit csak szolidan halad meg az átlagbér növekedési üteme), mégis egyre több férfi veszi igénybe (lásd: 6. táblázat). A támogatás összege 25\%-kal növekszik, ha az anya egyszerre több gyermeket szül, és felére csökken, ha az iskoláskorú gyermek a törvényben meghatározottnál többször marad ki az iskolából (Gerbery 2017: 354).

\section{Családi pótlék jellegü juttatások és egyéb támogatások}

A vizsgált országokkal összevetve Szlovákiának meglehetősen fejletlen a családi pótlék rendszere. A gyermek tanulmányaihoz kötődő családi pótlékra (prídavok na dieta) a szülők a tankötelezettség végéig (16 év), illetve felsőoktatási tanulmányok esetén a gyermek 25 éves koráig tarthatnak igényt. Ez utóbbi esetben akkor jár a családi pótlék, ha a gyermek egyetemi hallgató, illetve betegség miatt nem folytathat tanulmányokat vagy jövedelemszerző tevékenységet. Az egy gyermek után járó családi pótlék jelenlegi összege 23,52 euró. ${ }^{47}$ A családi pótlékot az állam tehát minden olyan személynek nyújtja, akinek eltartott gyermek neveléséről és létfenntartásáról kell gondoskodnia, feltéve, hogy eleget tesz a következő feltételeknek:

- a gyermeket ténylegesen eltartja,

- állandó vagy ideiglenes lakóhellyel rendelkezik Szlovákiában,

- az eltartott gyermek állandó vagy ideiglenes lakóhellyel rendelkezik Szlovákiában.

Igényelhető még kiegészítő családi pótlék (priplatok k prídavku na dieṫa), amely anyasági támogatáshoz kapcsolódva kerül folyósításra havi 11 euró értékben.

A tanulmányhoz kötött családi pótléknál sokkal fontosabb állami juttatásnak számít a gyermekgondozási segély (príspevok na starostlivos o dieṫa), amelyben a 3 évnél fiatalabb gyermekről gondoskodó szülők részesülhetnek (az igényt az egyik szülő nyújthatja be). Súlyosan beteg gyermek esetében a jogosultsági korhatár 6 év. A gyermekgondozási segélyt ugyanazon gyermek után csak az egyik szülő veheti igénybe. Az a szülő, aki anyasági támogatásban részesül, és annak mértéke alacsonyabb a gyermekgondozási segély összegénél, kérvényezheti a különbség kiegyenlítését. A támogatási forma állandó munkaviszonyhoz, vagy középfokú, felsőfokú tanulmányok folytatásához kötött. A kifizetések összegei a gyermekgondozás helyszínének és költségeinek függvényében módosulnak.

\footnotetext{
${ }^{47}$ http://ec.europa.eu/social/main.jsp?catld=1127\&intPageld=4761\&langld=en Letöltés: 2018. január 15.
} 
Ha a háztartás deklarált gyermekgondozási költségei elérik a maximum havi 280 eurót, a szülők igényelhetik ezt az összeget. Havi 41 eurót lehet igényelni akkor, ha nagyszülő vagy rokon gondozza a gyermeket, ez esetben nem szükséges deklarálni a gyermekneveléssel kapcsolatos költségeket. Havi 80 euró gyermekgondozási segélyt igényelhetnek a családok, ha a gyermek állami bölcsődébe vagy óvodába jár (Gerbery 2017: 354-355).

A cseh családi adókedvezmény rendszerrel összevetve a szlovák mechanizmus jóval kevésbé kiterjedt és redisztributív. A szülők évente fejenként 250 eurót irhatnak le az éves személyi jövedelemadójukból a gyermek 25 éves koráig. ${ }^{48}$ A szülési támogatás (príspevok pri narodeni dietata) olyan ellátás, amelynek révén az állam hozzájárul az újszülött alapvető szükségleteinek kielégítéséhez kapcsolódó költségek fedezéséhez. A juttatás átalányösszegü, és a gyermek születése után egy alkalommal jár. Születési támogatásra a szülést követően jogosult az anya, illetve az apa, ha az anya meghalt, vagy az 1 évnél fiatalabb gyermeket az apa neveli, valamint az örökbefogadó szülő. A juttatás iránti igényt a születéstől számított 6 hónapon belül kell benyújtani. A támogatás összege a harmadik gyermek születéséig 829 euró, a harmadik gyermek után pedig gyermekenként 151 euró. ${ }^{49}$

\section{BÖLCSŐDEI ÉS ÓVODAI ELLÁTÁSOK}

A többi szocialista országhoz hasonlóan 1990 előtt a bölcsődék (detské jasle) Csehszlovákiában is az egészségügyi minisztérium fennhatósága alá tartoztak. A rendszerváltás és Csehszlovákia felbomlása után azonban a szlovák bölcsődei rendszer kikerült az egészségügyi minisztérium felügyelete alól, és igazából semmilyen más kormányzati entitás alá nem tagozódott be, fenntartásuk teljes egészében a helyi önkormányzatok feladata lett. Ennek következtében a szlovák bölcsődei rendszer krónikusan alulszabályozott, nem léteznek megfelelő és univerzális képzettségi és curriculáris követelmények, nincsenek felügyeleti szervek, és semmilyen központi támogatás nem érhető el a bölcsődék számára. A helyzet további súlyos hozadéka, hogy nincsenek olyan központi szervezetek, amelyek számon tartanák a bölcsődei rendszerrel kapcsolatos alapvető adatokat (intézmények száma, regionális eloszlása, beíratott gyermekek száma, helyigények,

\footnotetext{
${ }^{48}$ http://visegradrevue.eu/family-policy-in-slovakia-in-urgent-need-of-reform/ Letöltés: 2018. január 15.

${ }^{49}$ http://tehotenstvo.rodinka.sk/prirucka-pre-rodica/peniaze-pre-rodicov/prispevok-pri-narodeni-dietata/ Letöltés: 2018. január 15.
} 
magánintézmények alapítása stb.). Ez lehetetlenné teszi egyrészt a bölcsődei szolgáltatások helyzetének felmérését, másrészt pedig az érdemi nemzetközi összevetést is (Gerbery 2010: 111).

A szocialista rendszer örökségének köszönhetően a szlovák óvodarendszer stabilabb formában vészelte át a rendszerváltás utáni éveket, bár az állami intézmények száma drasztikusan esett (1989-ben a szlovák területeken 4025 óvoda volt, 1994-re 3300, 2008-ban pedig már csak 2871 állami intézmény volt Szlovákiában) (Gerbery 2010: 114). Bár az óvodák (materské školy) formálisan az oktatási minisztérium fennhatósága alá tartoznak, az intézmények üzemeltetése, fenntartása (és igény esetén sokszor azok alapítása is) a helyi önkormányzatok feladatkörévé vált. Az oktatási minisztérium felügyeli és ellenőrzi az óvodákat, meghatározza az alapvető curriculáris követelményeket, de érdekes módon a helyi önkormányzatok meglehetősen magas szintű autonómiát élveznek a tananyag meghatározásában. Magánszemélyek vagy jogi entitások, valamint egyházak egyaránt alapíthatnak óvodákat, ezeknek az intézményeknek ugyanazon követelményeknek kell megfelelniük, mint az állami óvodáknak. ${ }^{50}$

A bölcsődei szolgáltatások súlyos hiányosságai Szlovákiában is az óvodarendszerben csapódnak le. Az elégtelen bölcsődehelyzet miatt 1994-től az óvodák kötelesek befogadni a 2 év feletti és 3 év alatti gyermekeket is ${ }^{51}$ (ez viszont még mindig azt jelenti, hogy a 2 év alatti gyermekek állami szintű felügyelete lényegében nem megoldott). Ahogy ezt Lengyelország és Csehország esetében már láthattuk, az eredmény itt is az óvodák túlterhelődése és súlyos óvodapedagógus-hiány lett. Gerbery (2010: 115) számításai szerint a 2 éves korú gyermekek nagyságrendileg 14-18\%-a jár óvodába (lásd: 7. táblázat), és a korai befogadási igények elutasítási rátája 1-2\% körül mozog. Az elutasítási arányból egyrészt arra lehet következtetni, hogy a 2 éves gyermekek elhelyezésének kérdése valószínüleg nem egy olyan akut problémakör, amelyre a szakpolitikának sürgősen válaszolnia kellene. Másrészt viszont az is valószínü, hogy sok szülő már eleve meg sem próbálja a 2 éves gyermekét óvodába adni, mivel biztosak a kategorikus elutasításban. Mivel az elutasított 2 éves gyermekek száma 1997 óta (ekkor 7805 2 évest nem vettek fel óvodába) szinte folyamatosan csökken, valószínűleg nem növekszenek az igények a korai óvodai elhelyezésre.

\footnotetext{
${ }^{50}$ http://unesdoc.unesco.org/images/0023/002302/230213E.pdf Letöltés: 2018. január 15.

${ }^{51} \mathrm{~A} 3$ év alatti gyermekek elfogadása az intézmény anyagi, oktatási és elhelyezési feltételei alapján hozott döntési körébe tartozik.
} 
7. táblázat: Adott életkori csoportok óvodalátogatási aránya Szlovákiában

The percentage of children attending kindergartens in Slovakia, by year of age

\begin{tabular}{cccccc}
\hline Év & 2 & 3 & 4 & 5 & $\begin{array}{c}\text { 3-5 évesek } \\
\text { összesen }\end{array}$ \\
\hline 1994 & 12,52 & 47,51 & 61,82 & 74,59 & 61,30 \\
1999 & 14,13 & 54,49 & 68,77 & 90,41 & 71,34 \\
2003 & 18,73 & 60,09 & 71,38 & 85,34 & 72,40 \\
2006 & 15,15 & 61,96 & 73,78 & 83,94 & 73,12 \\
2008 & 10,05 & 60,93 & 73,01 & 81,78 & 71,73 \\
\hline
\end{tabular}

Forrás: Gerbery (2010: 115) alapján saját szerkesztés.

Az oktatási minisztérium először 1997-ben fogalmazott meg átfogó programtervet az óvodai oktatás fejlesztésére. A tervezet két fő problémát azonosított: az egyre égetőbb óvodapedagógus-hiány és a képzettségük romlása, valamint a hátrányos helyzetü gyermekek integrációjának hiányosságai. 2008-ban az óvodai oktatásról szóló törvény és annak rendeleti kiegészítései az óvodát az iskolai oktatást előkészítő intézményként definiálták, amelynek célja a gyermekek személyes fejlődésének elősegitése. Azt már az 1997-es programterv is kilátásba helyezte, hogy valamennyi 5 éves gyermek számára hozzáférhető legyen az ingyenes, állami óvodai hely, mivel ebben a korban megy végbe a gyermekek felkészítése a kötelező általános iskolai tanulmányokra. Az 5 évesek óvodalátogatási aránya azonban 80-90\% között mozog, aminek nem utolsósorban az az oka, hogy a szlovák törvények nem teszik kötelezővé az iskolakezdés előtti egy évben az óvodáztatást. ${ }^{52}$

2014-ben 2870 óvoda volt, összesen 7525 csoporttal, amelyből 7201 kínált teljesnapos ellátást. 2014-ben óvodai oktatásban 1530592 és 7 év közötti gyermek vett részt, akiket 14841 óvodapedagógus felügyelt és oktatott. Ugyanebben az évben az UNESCO Education for all 2015 címú jelentése szerint 812 speciális óvoda múködött, amely összesen 1465 speciális nevelési igényű gyermeknek nyújtott szolgáltatásokat. A jelentés szerint 2014-ben az 5-6 éves gyermekek 91,7\%-a járt óvodába, és összesen 9682 kérelem volt függőben a 2013 szeptemberi évkezdéskor. A számok ugyanakkor nem fedik teljesen a keresleti-kínálati dinamikákat; egyrészt mert nem mindegyik szülő adja 5-6 éves korában óvodába gyermekét, másrészt pedig sok gyermek nem kezdi meg az iskolát 6 éves

52 http://unesdoc.unesco.org/images/0023/002302/230213E.pdf Letöltés: 2018. január 15. 
korban (évente nagyságrendileg 4500 gyermek). ${ }^{53}$ Az iskolát akár a szülő, akár az óvoda javaslatára később kezdő gyermekeknek az intézmények priorizált helyet biztosítanak.

Az óvodai kérelmek mérlegelésekor az intézmények nem mondhatnak ellent az érvényben lévő törvényi szabályozásoknak, nem diszkriminálhatnak (például nem tehetik befogadási feltétellé, hogy mindkét szülő dolgozzon, vagy hogy az adott településen legyen a bejelentett lakhelyük). Szabad helyek esetén az óvodák év közben is felvehetnek gyermekeket. A 2008-as óvodai törvények maximalizálták a csoportlétszámokat: maximum 20 fő lehet a 3-4 éves gyermekeket magukba foglaló csoportokban, 21 fő a 4-5 évesek csoportjaiban és 22 fő az 5-6 évesek csoportjaiban. Bizonyos esetekben (a család lakhelyváltozása, késleltetett iskolakezdés, a gyermek egészségügyi problémái) a vezető óvodapedagógus maximum három plusz főt tehet be az egyes csoportokba. Külön csoportokat lehet létrehozni az iskola-előkészítő oktatás céljából, különböző extracurriculáris tevékenységek (zene, sport) gyakorlására, vagy idegennyelvek tanulására (ezek a külön csoportok nem haladhatják meg a 12 főt). ${ }^{54}$

\section{KONKLÚZIÓ}

Tanulmányunkban rövid történeti kitekintésekkel megpróbáltuk bemutatni Lengyelország, Csehország és Szlovákia jelenlegi családtámogatási rendszereit. Mindhárom ország esetében megfigyelhető volt, hogy a rendszerváltás nem jelentett lényegi cezúrát a családpolitikai intézményrendszerek fejlődésében: az alapvető struktúrák és támogatási mechanizmusok nagyrészt a rendszerváltás előtti évtizedekben alakultak ki. Az 1990 utáni szakpolitikai mozgásokra általában jellemző volt, hogy a konzervatív pártok inkább a népesedéspolitikai irányultságot, míg a régió szociálliberális pártjai inkább a szociálpolitikai szempontokat kívánták érvényesíteni a családtámogatási modellekben. A konzervatív kormányzatok Lengyelországban és Csehországban is emelték az anyasági szabadságok időtartamát és a támogatások mértékét, illetve új ellátási formákat vezettek be. A szociálliberális kormányzatok jellemzően a pótlékjellegü juttatások szerepét növelték például Csehországban, és igyekeztek jövedelemteszteltté (és ezáltal jobban célzottá) tenni bizonyos ellátási formákat.

\footnotetext{
53 http://unesdoc.unesco.org/images/0023/002302/230213E.pdf Letöltés: 2018. január 15.

${ }^{54}$ http://unesdoc.unesco.org/images/0023/002302/230213E.pdf Letöltés: 2018. január 15.
} 
Mindhárom országra jellemző, hogy az állam és a kormányzatok a családtámogatási politikákon keresztül is igyekeznek szabályozni bizonyos munkaerőpiaci folyamatokat. Az anyasági támogatások kiterjesztése azonban megerősíti a családpolitikák genderizáló aspektusait. Ugyanakkor mindhárom ország kormányzatai próbálják növelni az apák gyermekgondozásban betöltött szerepét. A legkevésbé genderizáló tendenciák Lengyelországban megfigyelhetők, ahol a legrövidebb a fizetett anyasági támogatás, ezért a nők (a bölcsődei ellátórendszer fejletlensége ellenére) hamar visszatérnek a munkaerőpiacra. Az utóbbi 10-15 évben mindegyik ország rugalmasabbá tette a pénzbeli ellátások felhasználását: a szülők felváltva vagy több részletben is kivehetik a szülői szabadságokat. A fizetett anyasági szabadság után mindhárom ország rendkívül hosszú, 3-4 éves gyermeknevelési szabadságot biztosít a szülőknek, amelyet leginkább az anyák vesznek ki, ez pedig jelentősen rontja a nők munkaerőpiaci pozícióit.

Mindhárom országban mutatkoznak különböző formában megjelenő diszkrepanciák a pénzbeli ellátási formák és a gyermekgondozási lehetőségek között. A hosszúra nyújtható gyermeknevelési szabadságokat jellemzően nem egészíti ki széles körben elérhető bölcsődei ellátórendszer. Mindegyik országban súlyos bölcsődei férőhelyhiány mutatkozik, és az igények általában az óvodai ellátásra terhelődnek tovább. Lengyelországban a „nulladik” óvodai évfolyam keretében nyújtanak egyes óvodák bölcsődei jellegủ szolgáltatásokat, Csehországban pedig az óvodák befogadhatnak 3 év alatti gyermekeket is. Ez viszont az óvodai ellátás szintjén jelent férőhely és erőforrás problémákat. A bölcsődei férőhelyek hiánya, és a négy évre nyújtható gyermeknevelési szabadság nagymértékben felelős a cseh nők körében tapasztalható rossz foglalkoztatási mutatókért. A bölcsődei szolgáltatások rugalmassága különösen fontos szempont lehet a gyermeknevelés állami segitése kapcsán: Csehországban például bizonyos pénzbeli gyermeknevelési támogatások csak akkor folyósithatók, ha a gyermek egy bizonyos időnél többet nem tartózkodik a bölcsődében vagy az óvodában.

A családpolitikai modellek értékelése kapcsán egyszerre kell tekintetbe venni azt, hogy az országok intézkedéscsomagjai milyen népesedéspolitikai és szociálpolitikai eredményeket értek el. Fontos megjegyezni, hogy nincs szakirodalmi konszenzus, hogy az egyes családtámogatási mechanizmusok milyen népesedés- és tágabb szociálpolitikai eredményekhez (például gyermekszegénység csökkenése, nők munkaerőpiaci helyzetének javulása, hátrányos helyzetű családok segítése) vezetnek. A rendszerváltás utáni évek demográfiai mélypontjai valamennyi országban előtérbe állították a családtámogatási modellek népesedéspolitikai aspektusait. A szakértők többsége ezzel kapcsolatban arra hívja 
fel a figyelmet, hogy rendkívül nehéz kauzális szintű kapcsolatot találni a születéstámogató intézkedések és a születések számának emelkedése között. Ezzel összefüggésben Neyer és Anderson (2008: 719) azt hangsúlyozzák, hogy nemzetközi összevetésekben nem mutatható ki, hogy melyek azok a népesedéspolitikai intézkedések, amelyek hasonló jellegű demográfiai változásokat okoznak az egyes országokban. Ennek részben az lehet az oka, hogy minden családpolitika egy komplex és országonként különböző szocioökonómiai és szociokulturális struktúrán keresztül fejti ki hatását. Gauthier (2007) szerint a kifejezetten népesedéstámogató családpolitikai intézkedések hatása inkább kimutatható például a gyermekszületés időzítésének változásában, mint a valódi és állandó termékenységnövekedésben. A családpolitikai és születésösztönző programok csak egyik tényezőjét jelentik a gyermekvállalási döntéseknek, emellett nagy szerepe lehet például a párkapcsolati viszonyoknak, a munkaerőpiaci helyzetnek, vagy az egyes társadalmi csoportok által vallott értékrendeknek is. Jelen tanulmány keretei között egyáltalán nem elemeztük a lakáshelyzet és a szülési kedv öszszefüggéseit, mindazonáltal a családalapítást ösztönző lakáspolitikáknak fontos népesedésügyi vonzatai vannak (lásd például: Mulder-Billari 2010, Mulder-ClarkWagner 2006).

Mindez azt is jelenti, hogy a bemutatott országok alacsony fertilitási mutatóit természetesen nem lehet csak a családpolitikai támogatási modellek számlájára írni. Ugyanakkor azonosítható néhány olyan tendencia, amelyre a családpolitikák adekvát reagálása szükséges. Egyrészt világszerte növekszik a házasságon kívül született gyermekek száma, viszont a vizsgált országok támogatási rendszerei egyelőre csak korlátozottan igazodtak ehhez a trendhez. Másrészt az elmúlt évtizedek nemzetközi tapasztalatai azt is világosan mutatják, hogy a fejlett országokban a nők magas szintű foglalkoztatása korrelál a magas gyerekszámmal. Ebben az értelemben a három közép-európai ország esetében valószínűleg okozati összefüggés áll fenn az alacsony fertilitási mutatók, illetve a rendkívül hosszú gyermeknevelési szabadságok és a relatíve fejletlen bölcsődehálózatok között. A demográfusok többsége egyetért abban, hogy a jól fejlett, könnyen elérhető bölcsődehálózatok érdemben képesek segíteni a nők munkaerőpiaci helyzetét, és ezen keresztül növelhetik a szülési kedvet is. 


\section{IRODALOM}

Avram, Silvia - Militaru, Eva 2016: Interactions Between Policy Effects, Population Characteristics and the Tax-Benefit System: An Illustration Using Child Poverty and Child Related Policies in Romania and the Czech Republic. Social Indicators Research, 128(3), 1365-1385.

Blum, Sonja - Formánková, Lenka - Dobrotič, Ivana 2014: Family Policies in 'Hybrid' Welfare States after the Crisis: Pathways between Policy Expansion and Retrenchment. Social Policy \& Administration, 47(4), 468-491.

Darvas Ágnes - Mózer Péter 2004: Kit támogassunk? Esély, 2004/6, 64-99.

Ferge Zsuzsa 2017: Magyar társadalom és szociálpolitika 1990-2015. Osiris, Budapest.

Frejka, Tomas - Gietel-Basten, Stuart 2016: Fertility and Family Policies in Central and Eastern Europe after 1990. Comparative Population Studies, 41(1), 3-56.

Gauthier, Anne 2007: The impact of family policies on fertility in industrialized countries: a review of the literature. Population Research and Policy Review, 26(3), 323-346.

Gerbery, Daniel 2010: Public childcare in the Slovak republic: development, outcomes and public attitudes. Manka goes to work. Public childcare in the Visegrad countries 1989-2009. Budapest Institute for Policy Analysis, Budapest, 107-124.

Gerbery, Daniel 2017: Slovak Republic country note. In Blum, Sonja - Koslowski, Alison Moss, Peter (eds.): International review of leave policies and research 2017, 352-357.

Hašková, Hana - Mariková, Hana - Unde, Zuzana 2009: Leaves, Allowances, and Facilities: Childcare Past and Present. In Hašková, Hana - Uhde, Zuzana (eds.): Women and Social Citizenship in Czech Society: Continuity and Change. Institute of Sociology, Prague.

Hašková, Hana - Uhde, Zuzana (eds.) 2009: Women and Social Citizenship in Czech Society: Continuity and Change. Sociologický ústav AV ČR, Praha.

Hašková, Hana 2010: Factors contributing to the decline in childcare services for children under the age of three in the Czech Republic. In Ágota Scharle (ed.): Manka goes to work. Public childcare in the Visegrad countries 1989-2009. Budapest Institute for Policy Analysis, Budapest, 4-21.

Information about family policy system in the Czech Republic (2009). Czech Presidency of the Council of the EU 2009. Ministry of Labour and Social Affairs of the Czech Republic.

Inglot, Thomasz 2008: Welfare States in East Central Europe, 1919-2004. Cambridge University Press, Cambridge.

Inglot, Thomasz - Szikra, Dorottya - Raț, Cristina 2012: Reforming post-communist welfare states: Family policy in Poland, Hungary, and Romania since 2000. Problems of Post-Communism, 59(6), 27-49.

Inglot, Thomasz 2016: Path-dependency versus Reform in Pensions and Family Policy Re-examined: Dual Trajectories of the Polish Welfare State since the 1990s. Social Policy \& Administration, 50(2), 241-261.

Jahoda, Robert - Jana, Godarová 2013: Family policy in the Czech Republic: Redistribution of wealth through the child tax bonus. Acta Universitatis Agriculturae et Silviculturae Mendelianae Brunensis, 61(7), 2213-2210. 
Kolaczek, Bozena 2007: Investment in youth and the equal chance principle in family and education policy. Polityka Społeczna/Social Policy, Special issue: Family policy in Poland, 34(8), 38-45.

Kocourková, Jirina 2017: Czech Republic country note. In Blum, Sonja - Koslowski, Alison - Moss, Peter (eds.): International review of leave policies and research 2017, 265-273.

Kurowska, Anna - Michon, Piotr 2017: Slovak Republic country note. In Blum, Sonja - Koslowski, Alison - Moss, Peter (eds.): International review of leave policies and research 2017, 265-273.

Kucharová, Vera 2010: Supply and demand for children's day-care facilities and its determinants in the Czech Republic. Manka goes to work. Public childcare in the Visegrad countries 1989-2009. Budapest Institute for Policy Analysis, Budapest, 21-41.

Lange Milena - Fratczak, Ewa 2010: Day care services for Children in Poland, 1980-2008. Manka goes to work. Public childcare in the Visegrad countries 1989-2009. Budapest Institute for Policy Analysis, Budapest, 96-106.

Mulder, Clara - Clark, Willam - Wagner, Michael 2006: Resources living, arrangements and first union formation in the United States, the Netherlands and West Germany. European Journal of Population, 22(1), 3-35.

Mulder, Clara - Billari, Francesco 2010: Homeownership and Low Fertility. Housing Studies, 25(4), 527-541.

Neyer, Gerda - Anderson, Gunnar 2008: Consequences of Family Policies on Childbearing Behavior: Effects or Artifacts? Population and Development Review, 34(4), 699-724.

Ocenasova, Zuzanna - Sotirovic, Vilana 2015: Europeanization of Family Policies: Comparative Analysis of Policy Discourses on Gender Equality in Care Policies in Czech Republic, Lithuania and Slovakia. http://gs.elaba.It/object/elaba:18887767/index.html Letöltés: 2018. január 15.

Rodin, Johnny 2011: Fertility Intentions and Risk Management: Exploring the Fertility Decline in Eastern Europe During Transition. Ambio, 40(2), Coping with Complexity in Baltic Sea Risk Governance, 221-230.

Saxonberg Steven - Sirovátka Tomas 2009: Czech family policy: Refamilialization in the face of contradictory public attitudes. Journal of Societal \& Social Policy, 7(3), 95-106.

Saxonberg, Steven 2014: Gendering Family Policies in Post-Communist Europe. A Historical-Institutional Analysis. Palgrave MacMillan, Basingstoke.

Sobotka, Tomáš 2002: Ten years of rapid fertility changes in the European post-communist countries: Evidence and interpretation. Population Research Centre Working Paper Series, 1 .

Sowa, Agnieszka 2016: Family 500+: A new family income-supporting benefit in Poland. ESPN Flash Report, 2016/45. Compiled by: Agnieszka Sowa (European Social Policy Network).

Steinhilber, Silke 2005: Gender and Post-socialist Welfare States in Central Eastern Europe: Family Policy Reforms in Poland and the Czech Republic Compared. In Razavi Shahra - Hassim, Shireen (eds): Gender and Social Policy in a Global Context. Social Policy in a Development Context. Palgrave Macmillan, London, 68-86. 
Suwada, Katarzyna - Plantin, Lars 2014: On Fatherhood, Masculinities, and Family Policies in Poland and Sweden - a Comparative Study. Polish Sociological Review, 188 (4), 509-524.

Szelewa, Dorota 2006: Three faces of familialism: comparing family policies in the Czech Republic, Hungary and Poland. Paper proposed for the RC19 Annual Academic Conference: Social Policy In a Globalizing World: Developing A North-South Dialogue, Florence 6-8 September 2006.

Thornton, Arland - Philipov, Dimiter 2009: Sweeping Changes in Marriage, Cohabitation and Childbearing in Central and Eastern Europe: New Insights from the Developmental Idealism Framework. European Journal of Population, 25(2), 123-156.

van de Kaa, Dirk 1987: Europe's second demographic transition. Population Bulletin, 42(1), 1-59.

Válková, Jana 2010: What is the direction of the Czech childcare policy? Manka goes to work. Public childcare in the Visegrad countries 1989-2009. Budapest Institute for Analysis, Budapest, 41-57. 


\title{
COMPARISON OF THE FAMILY POLICIES OF POLAND, CZECH REPUBLIC AND SLOVAKIA
}

\begin{abstract}
This study offers a comparison between the family policy models of Poland, Czech Republic and Slovakia. The author examines the financial benefits these countries provide for families (such as paid and unpaid maternity leaves, parental leaves, family allowances and family tax credits) and their childcare systems. Since the current family policy frameworks cannot be understood without exploring the historical background of these institutions the author shortly analyse how these welfare policies became highly politicized after the transitions. The basic institutional structures and distributive mechanisms that evolved in the socialist era survive in every examined country. Every countries' welfare provisions experienced severe crises in the 1990s, and the demographic downturns and social tensions were both the causes and the results of the collapse of the welfare state. The reforms and fine-tuning of these provisions were often subordinated to political goals, but these patterns were not consequent. For example the strong influence of the Polish Catholic church on childcare hindered the evolvement of a strong nursery and kindergarten network, as compared with other CEE countries with similar historical experiences. The Czech Republic has a well-developed family policy framework that can be considered as the reason for higher fertility rates.
\end{abstract}

